\title{
КРИТИЧЕСКИЕ ТОВАРНЫЕ ПОТОКИ МАРГАНЦЕВОГО СЫРЬЯ В РОССИИ
}

\author{
Боярко Григорий Юрьевич 1 , \\ gub@tpu.ru
}

\author{
Хатьков Виталий Юрьевич2,1, \\ vitaliy@payler.com \\ 1 Национальный исследовательский Томский политехнический университет, \\ Россия, 635050, г. Томск, пр. Ленина, 30. \\ 2 ПАО «Газпром», \\ Россия, 196143, г. Санкт-Петербург, пл. Победы, 2.
}

\begin{abstract}
Актуальность работы обусловлена необходимостью изучения проблем импортозависимости России по марганцевому сырью. Цель: изучение динамики товарных потоков (производства, импорта, экспорта, потребления) марганцевых продуктов (руд и концентратов, ферромарганца, слиликомарганца и марганца металлического); выработка рекомендаций по оптимизации товарооборота марганцевых продуктов.

Методы: статистический, графрический, логический.

Результаты. Марганцевые продукты являются одним из самых массовых импортозависимых товаров России, которых в 2018 г. суммарно импортировано свыше 1,6 млн m, что составляет 72 \% от их потребления. Импортозависимость по марганцевым рудам по состоянию на 2018 г. составляет $100 \%$ от потребления (импортировано 1318 тыс. m), по силикомарганuу - 46 \% (импорт 192 тыс. m), по марганцу металлическому - 100 \% (импорт 68 тыс. m) и по ферромарганиу - 10 \% (импорт 21 тыс. т). Потребление марганцевого концентрата увеличилось с 285 тыс. т в 1996 г. до 1,3 млн т в 2018 г. (+7,2 \%/год). Вближайшее время черная металлургия России не сможет обойтись без импорта марганцевого концентрата. Требуется серьезное упорядочение импортных поставок марганцевого концентрата из Казахстана, Южно-Афрриканской Республики и Габона, а также российские инвестиции в зарубежные марганцедобывающие и ферросплавные компании. Национальное потребление силикомарганца увеличилось с 170 тыс. m в 1998 г. до 455 mыс. m в 2017 2. (+5,3 \%/2од), а производство возросло с 50 до 355 тыс. m/2од (+6,5 \%/год). Объемы импорта силикомарганца остаются на прежнем уровне - 170-190 mыс. m/2од, хотя в 2003-2008 г2. они составляли 310-435 mыс. m/год. Сокративщийся импорт с Украины замещен поставками из Грузии, Казахстана и Норвегии. Национальное потребление ферромарганца увеличилось незначительно - с 193 тыс. m в 1996 г. до 262 mыс. $m$ в 2017 г. (+0,6 \%/год), причем объемы производства резко возросли с 50 до 260 тыс. m/2од (+6,5 \%/год). Объемы импорта фрерромарганца при этом серьезно сократились с 130 до 21 тыс. m/год (-3,9 \%/год). Ферромарганец вышел из полной импортной зависимости в импортонезависимую категорию. Появился спрос на новый товарный продукт - марганец металлический, потребление которого выросло с 0,3 тыс. m в 1996 г. до 68 тыс. m в 2018 г. (+12,2%/год). На фоне тотального импорта марганцевых ферросплавов появилось явление встречной импортно-экспортной торговли (экспорт до 63 тыс. m/год ферромарганца и до 133 тыс. m/год силикомарганца), вплоть до формирования направления нетто-экспорта ферромарганца (до 41 тьс. m/год ферромарганца).
\end{abstract}

\section{Ключевые слова:}

Ферросплавная промышленность России, марганцевые руды и концентраты, фрерромарганец, силикомарганец, марганец металлический, импортозависимость, встречные товарные потоки.

\section{Введение}

Марганеи - традиционный легирующий металл, используемый в производстве ферросплавов (ферромарганца и силикомарганца) для раскисления сталей при плавке, производства легированных чугуна и стали, а также для изготовления марганецсодержащих бронз, латуней и других сплавов с цветными металлами, обладающих антикоррозийными свойствами. До 10 \% марганца потребляется в электротехнической (производство сухих батарей) и в химической промышленности.

Исходным сырьем для производства марганцевых сплавов являются оксидные, карбонатные, силикатные и смешанные марганцевые руды. Наиболее качественными являются оксидные марганцевые руды, из которых наибольшую ценность представляют пиролюзитовые и богатые псиломелан-пиролюзитовые руды. Богатые руды непосредственно являются товарным продуктом, а бедные обогащают для получе- ния концентратов, содержащих свыше 36 \% Mn [1]. Товарными продуктами марганцевого минерального сырья являются: марганиевые руды и концентраты, ферромарганец, силикомарганеч и марганец металлический.

В результате образования на постсоветском пространстве новых стран СНГ произошло разрушение экономических связей самодостаточного минеральносырьевого комплекса и потребляющих отраслей промышленности СССР. Переориентация национальных экономических интересов привела к изменению рынков минерального сырья, в первую очередь для обеспечения собственных нужд, а также к появлению новых направлений товарных потоков сырья. Если СССР до 1991 г. был мировым лидером по добыче марганцевого сырья, то в России, где его добыча просто отсутствовала, сформировались критические импортные потоки марганцевых руд и концентратов (свыше 250 тыс. т/год, $95 \%$ от потребления), ферромарганца 
(свыше 200 тыс. т/год, 70 \%) и силикомарганца (свыше 150 тыс. т/год, 70 \%). В начале XXI в. появился новый импортный поток марганца металлического (до 68 тыс. т/год, $100 \%$ от потребления). Кроме этого, ферросплавные заводы, используя свободу для маневра реализации продукции, в отдельные годы направляли производственные феррослоавы на экспорт, создавая встречные импортно-экспортные потоки ферромарганца (до 63 тыс. т/год, 48 \% от производства) и силикомарганца (до 133 тыс. т/год, 70 \%) [1, 2]. Импортозависимость по марганцевому сырью, собственно, свойственна всем странам-лидерам металлургического производства США (100 \% по импорту) [3], странам Европейского Союза (90\%) [4], Китаю (до 60 \%), Индии (до 50 \%), Японии (100\%), Южной Кореи (100 \%) [5].

\section{Методы исследований}

С целью изучения российского рынка марганцевых продуктов были обработаны данные по движению их товарных потоков за 1996-2018 гг., по динамике их мировых цен и цен российского импорта и экспорта. Источники информации: Государственные доклады Федерального агентства недропользования Российской Федерации [6], статистические данные Федеральной службы государственной статистики [7] и Федеральной таможенной службы [8] России, обзоры информационных центров $[5,9,10]$.

Объемы товарных потоков марганцевого сырья учтены в метрических тоннах, а цены - в долларах США за тонну товара. Обобщенные суммарные объемы марганцевых продуктов приведены в пересчете на $100 \%$ Mn. Доли импорта определялись по отношению импортных объемов к объемам национального потребления и реализации (потребления + экспорта), доли экспорта - по отношению экспортных объемов к объемам национального производства. Среднемировые цены марганцевых продуктов рассчитаны как средневзвешенные данные цен главных странэкспортеров марганцевого сырья. Темпы годовых изменений во времени абсолютных показателей (объемы, стоимость) определяются в виде сложных процентов, относительных показателей (цены, доли) - в виде простых процентов.

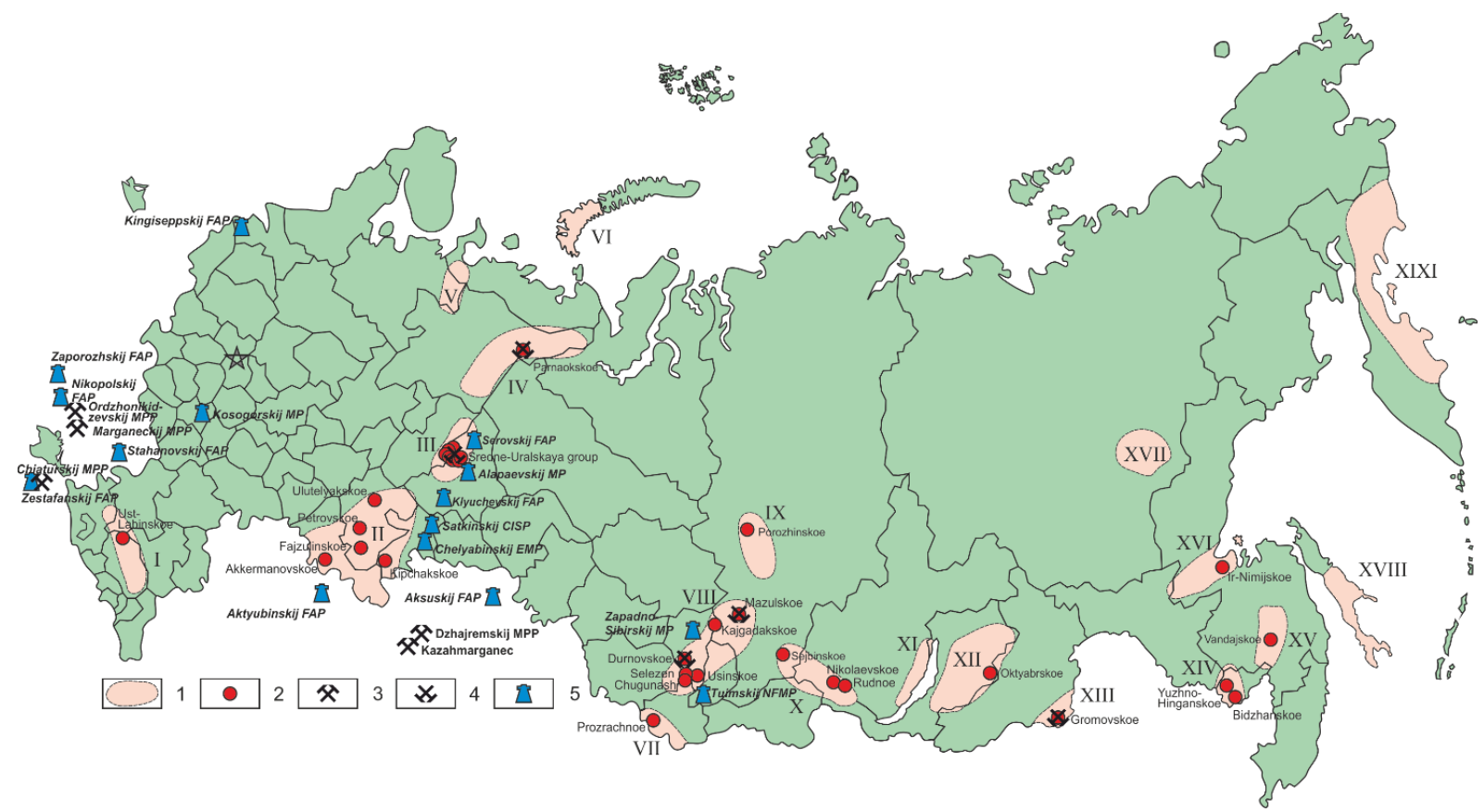

Pис. 1. Марганценосные провиници, месторождения маргания; предприятия, добывающие, перерабатывающие и потребляющие марганщевое сырье: 1 - марганщеносные провинции (I - Северо-Кавказская, II - ЮжноУральская, III - Средне-Уральская, IV - Полярно-Уральская, V-Северо-Тиманская (Архангельская), VI - Новоземельская, VII - Алтайская, VIII - Салаиро-Кузнечкая, IX - Енисейская, X-Восточно-Саянская, XI - Прибайкальская, XII - Забайкальская, XIII - Приаргунская, XIV - Хинганская, XV - Средне-Амурская, XVI - Удско-Шантарская, XVII - Усть-Майская, XVIII - Сахалинская, ХIX - Камчатская); 2 - месторождения марганща; 3, 4-марганцедобывающие предприятия (3 - действующие, 4-законсервированнье); 5 - металлургические предприятия, потребляющее марганцевое сырье

Fig. 1. Manganese provinces, manganese deposits; companies and plants producing, processing and consuming manganese raw materials: 1 - manganese provinces (I - Severo-Kavkazskaya, II - Yuzhno-Uralskaya, III - Sredne-Uralskaya, IV - Polyarno-Uralskaya, V-Severo-Timanskaya (Arkhangelskaya), VI - Novozemelskaya, VII - Altayskaya, VIIISalairo-Kuznetskaya, IX - Eniseyskaya, X - Vostochno-Sayanskaya, XI - Pribaykalskaya, XII - Zabaykalskaya, XIII - Priargunskaya, XIV - Khinganskaya, XV - Sredne-Amurskaya, XVI-Udsko-Shantarskaya, XVII - Ust-Mayskaya, XVIII - Sakhalinskaya, XIX - Kamchatskaya); 2 -manganese deposits; 3, 4-manganese mining companies (3-active, 4 -stopped); 5 - metallurgical companies and plants that consume manganese materials 
Состояние марганцевых добывающих и ферросплавных производств в России

Ситуация по обеспечению черной металлургии России марганцевым сырьем остается крайне напряженной $[1,2,11-17]$. После распада СССР практически все предприятия, добывающие марганец, остались за пределами России (на Украине, в Грузии и Казахстане). В настоящее время 100 \% внутреннего российского потребления марганцевой руды и около 40 \% потребления марганцевых сплавов удовлетворяется за счет импорта.

Добыча марганцевых руд на территории России осуществляется в небольших объемах и спорадически - на Парнокском месторождении в Республике Коми, Тыньинском месторождении в Свердловской области, Громовском месторождении в Забайкальском крае, Дурновском месторождении в Кемеровской области и Мазульском месторождении в Красноярском крае (рис. 1). В 2013 г. была достигнута максимальная добыча в 66 тыс. т, но в 2014 г. промышленная разработка марганцевых руд в России была прекращена.

Подготавливаются к эксплуатации Усинское месторождение марганцевых руд в Кемеровской области (ЗАО «ЧЕК-СУ.ВК») и Южно-Хинганское месторождение в Еврейской АО (китайская компания ООО «Хэмэн Дальний Восток»). Периодический интерес вызывает возможная разработка крупного Порожинского месторождения в Красноярском крае.

Общий уровень национального потребления марганцевых руд и концентратов прямо пропорционален динамике выпуска российскими металлургическими предприятиями стальной продукции; он вырос с 284 тыс. т в 1996 г. до 1276 тыс. в 2018 г. со среднегодо-
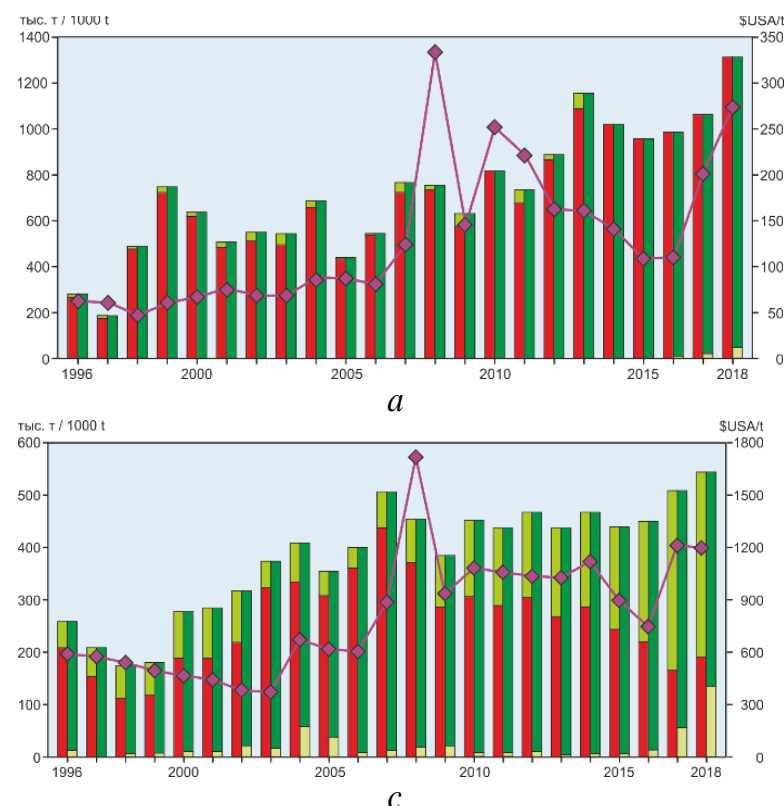

вым приростом $+7,2 \%$ (рис. $2, a$ ). Доля импорта при этом составляет в разные годы от 91,2 до $100 \%$ (рис. 3). Среднегодовой прирост объемов импорта марганцевых руд и концентратов составил за этот период $+7,4$ \%. Стоимость годового импорта марганцевого сырья составляла 34-57 млн \$ США в период 1999-2007 гг., увеличилась до 245 млн \$ США к 2008 г., упала в результате финансового кризиса до 51 млн \$ США в 2011 г. и восстановила тенденцию роста вплоть до 365 млн \$ США в 2018 г. (рис. 3, a). Доля стоимости марганцевых руд и концентратов, длительное время составлявшая 15-25 \% от суммы марганцевых продуктов, начиная с 2016 г. стала расти, вплоть до 47,3 \% в 2018 г. (рис. 3, b).

С увеличением переработки марганцевых руд на украинских заводах к 2000 г. была прекращена отгрузка никопольского марганцевого концентрата на российские ферросплавные заводы. Этот отток был компенсирован увеличением импорта из Казахстана и появлением новых потоков марганцевого сырья из Южно-Африканской Республики и Габона (рис. 5, $a$ ). Импорт марганцевого концентрата из Казахстана в 1999-2014 гг. составлял 335-670 тыс. т/год, но в последние годы он сократился, вплоть до 128 тыс. т в 2018 г. Начиная с 2006 г. осуществляются поставки марганцевого сырья из Южно-Африканской Республики, увеличившиеся к 2018 г. до 843 тыс. т. С 2016 г. начаты поставки высококачественных марганцевых руд из Габона, достигшие в 2018 г. 338 тыс. т. Осуществляются также закупки марганцевого концентрата из Болгарии (до 191 тыс. т/год), Австралии (до 87 тыс. т/год), Бразилии (до 52 тыс. т/год) и Грузии (до 28 тыс. т/год).
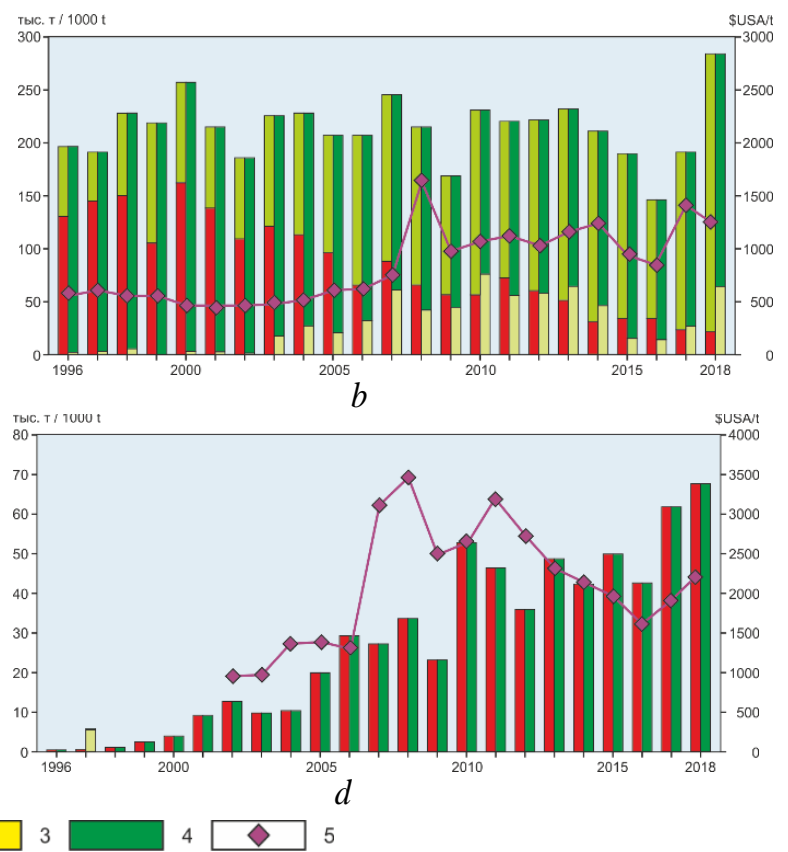

Pис. 2. Балансы рынков марганиевого сырья в России за 1996-2018 г2. Составлено по данным [6-10]: а) марганцевых руд и концентратов; b) ферромарганиа; с) силикомарганиа; d) марганца металлического. 1 - импорт, 2 - производство, 3 - экспорт, 4 - нетто-потребление, 5 - иены импорта

Fig. 2. Balance of the markets of manganese raw materials in Russia for 1996-2018. Based on the data [6-10]: a) manganese ores and concentrates; b) ferromanganese; c) silicomanganese; d) metal manganese. 1 - import, 2 - production, 3 - export, 4 - net consumption, 5 - import prices 


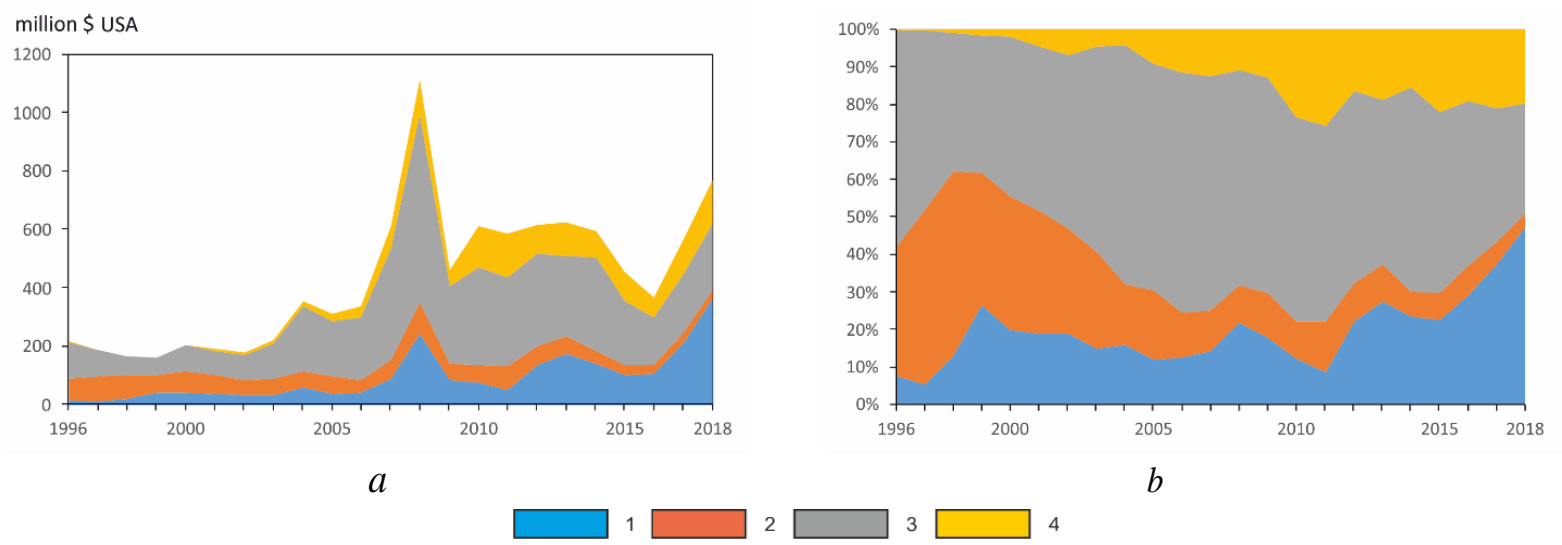

Рис. 3. Динамика стоимости импорта в Россию марганцевых продуктов (a) и их долей (b) за 1996-2018 г2. 1 - марганиевые руды и концентраты, 2 - ферромарганеи, 3 - силикомарганеи, 4 -марганец металлический

Fig. 3. Dynamics of the value of import to Russia manganese products (a) and fraction (b) for 1996-2018. 1 - manganese ore, 2 - silicomanganese, 3 -ferromanganese, 4 - metal manganese

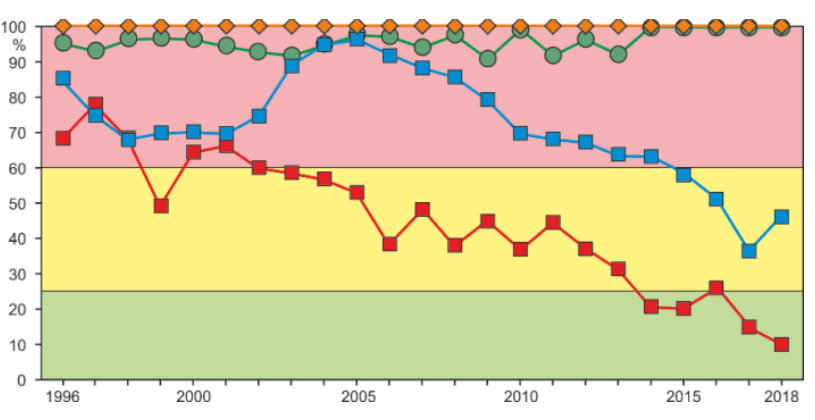

Pис. 4. Динамика долей импорта (от потребления) марганцевых продуктов за 1996-2018 ге. О - марганцевых руд и конщентратов, $\mathbf{-}$ - ферромарган-

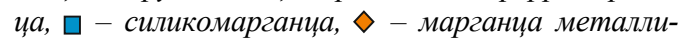
ческого. Зеленая область - отсутствие импортозависимости, желтая - низкая импортозависимость, красная - высокая импортозависимость

Fig. 4. Dynamics of share of import (consumption) of manganese products for 1996-2018. o - manganese ores and concentrates, $\square-$ ferromanganese, $\square-$ silicomanganese, $\diamond-$ metal manganese. Green area - no import dependence, yellow - low import dependence, red - high import dependence
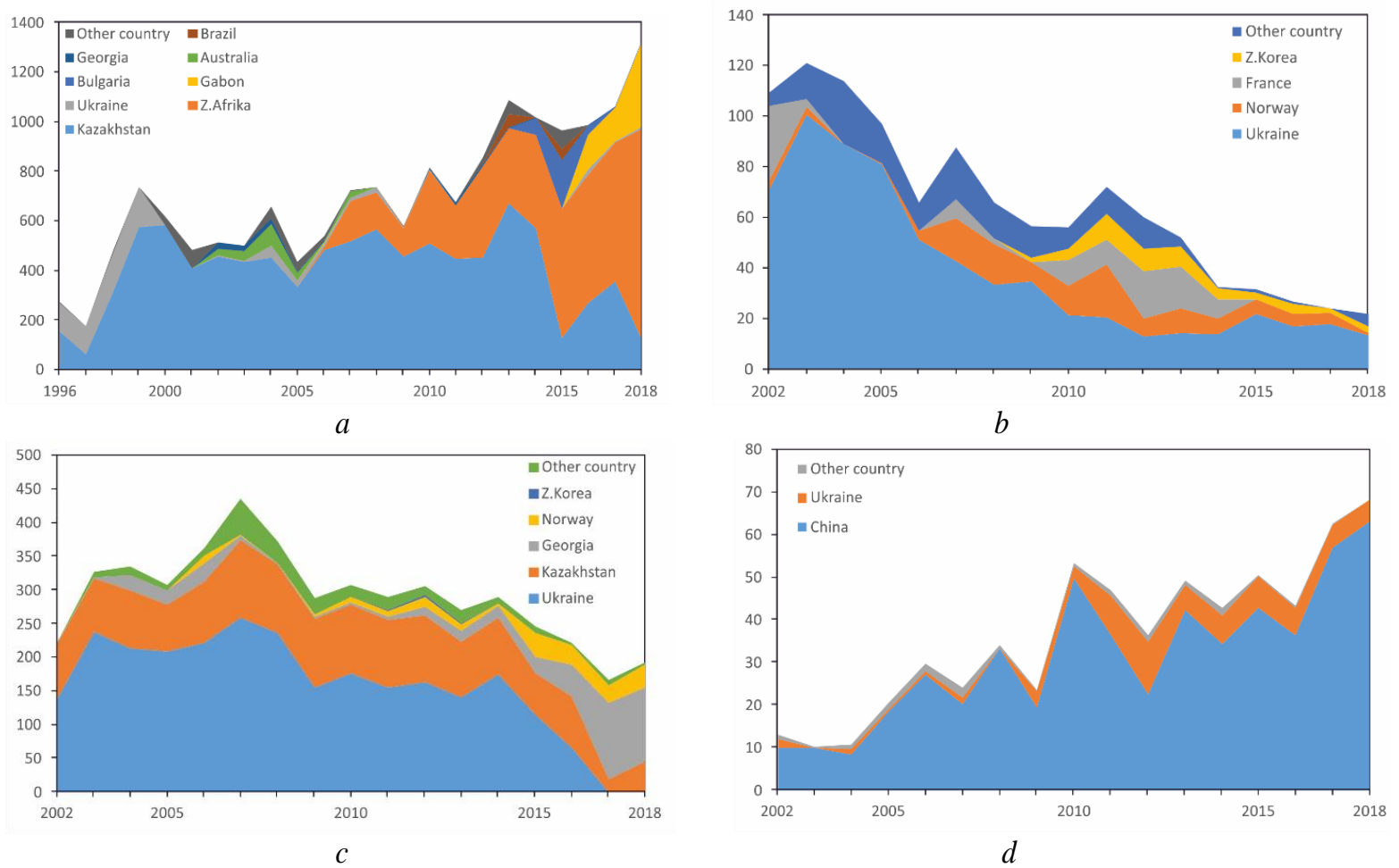

Pис. 5. Динамика объемов импорта по странам-продавиам: марганщевых руд и конщентратов за 1996-2018 г2.: а) ферромарганца; b) силикомарганца; с) марганиа металлического; d) за 2002-2018 гz., тыс. т. Составлено по данным Федеральной таможенной службы РФ [8]

Fig. 5. Dynamics of import volume by exporting countries: manganese ores and concentrates for 1996-2018: a) ferromanganese; b) silicomanganese; c) metal manganese; d) for 2002-2018, kt. Based on the data [8] 
Экспорт марганцевых руд и концентратов из России крайне незначителен и составляет максимум 46 тыс. т $(3,5 \%$ от реализации [потребления + экспорта]) в 2018 г.

Среднемировые экспортные цены на марганцевые руды и концентраты (рис. $6, a$ ) имеют четыре временных тренда: стабильный уровень 55-90 \$ США/т в период 1996-2006 гг.; рост цен до абсолютного максимума 296 \$ США/т в 2008 г. и последующая просадка до 133 \$ США/т в 2009 г.; спад цен в период 2010-2016 гг. с 205 до 107 \$ США/т и последний рост до максимума в 232 \$ США/т в 2018 г. Цены импорта марганцевого концентрата в Россию лишь изредка (1996-1999, 2003-2004 гг.) были ниже среднемировых цен, в остальные периоды российский импорт был на 15-30 \% дороже среднемирового уровня. Впрочем, цена на концентрат дифференцирована в зависимости от качества руд, и повышенные цены российского импорта свидетельствует о значительной доле высококачественных руд в объемах импорта (из Габона, Бразилии и ЮАР). В то время основная масса поставок марганцевых руд среднего качества из Республики Казахстан поступает по ценам, на 5-35 \% ниже среднероссийских импортных цен.

Основными потребителями марганцевых руд являются российские предприятия, выпускающие марганцевые ферросплавы (рис. 1):

- $\mathrm{AO}$ «Серовский завод ферросплавов» в г. Серов Свердловской области;

- ООО «Саткинский чугуноплавильный завод» в г. Сатка Челябинской области;
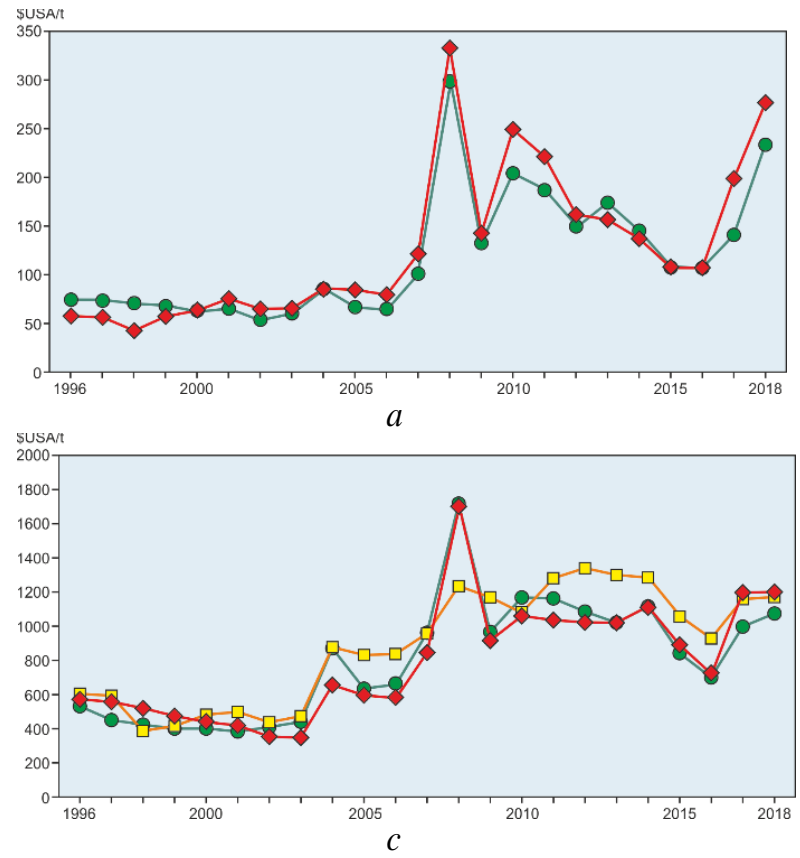

- ООО «Алапаевский металлургический завод» в г. Алапаевске Свердловской области;

- ПАО «Ключевский завод ферросплавов» в пос. Двуреченск Свердловской области;

- АО «Челябинский электрометаллургический комбинат» в г. Челябинск;

- ПАО «Косогорский металлургический завод» в г. Тула;

- АO «Кингисеппский ферросплавный завод» в г. Кингисепп Ленинградской области.

Производство марганцевых ферросплавов из марганцевых руд осуществляется доменным, электрометаллургическим и гидрометаллургическим способами [11].

Хотя мощности по производству ферросплавов России (290 тыс. т/год по ферромарганцу [5] и 410 тыс. т/год по силикомарганцу [6]) позволяют полностью обеспечить металлургические предприятия страны марганцевой продукцией дефицит сырой руды и значительные издержки на ее транспортировку делают эти предприятия менее эффективными. Они испытывают значительную конкуренцию со стороны иностранных производителей ферросплавов, и, соответственно, существуют проблемы по замещению импортных поставок марганцевых ферросплавов [13-16].

На рис. 2, $b$ показана динамика рынка ферромарганияа в России. Производство ферромарганца в России имеет тенденцию к росту с 46 тыс. т (25\% от национального потребления) в 1997 г. до 262 тыс. т в 2018 г. (превышает российское потребление) со среднегодовым приростом $+6,5 \%$. Национальное потребление ферромарганца составляет 170-220 тыс. т/год.
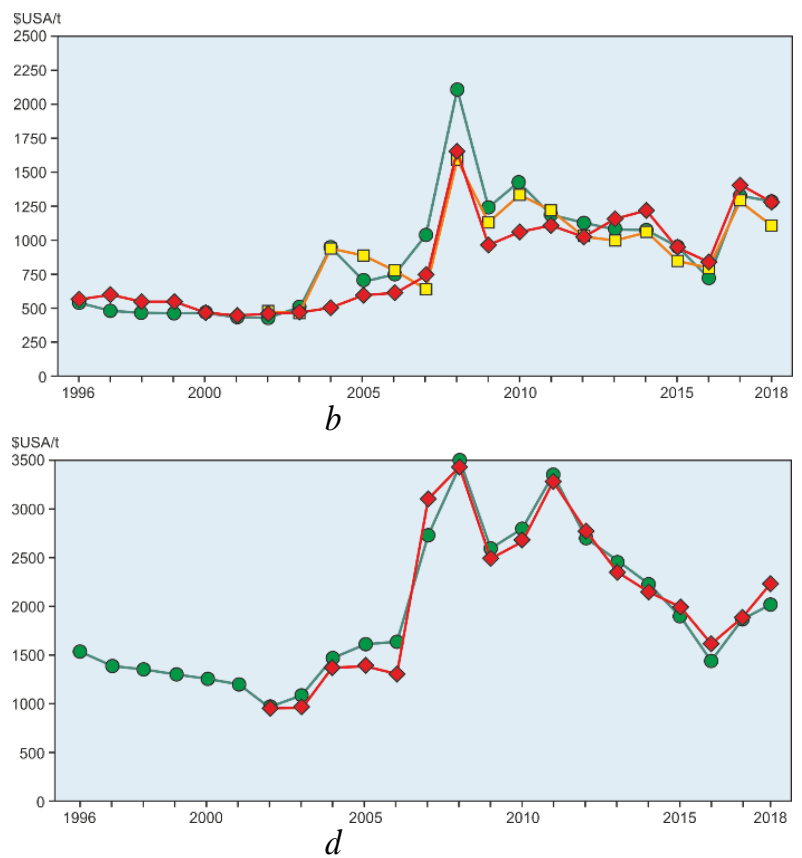

Pис. 6. Динамика иен на марганцевые продукты за 1996-2018 г2. Составлено по данным [7-9]: а) марганцевые руды и концентраты; b) ферромарганеи; с) силикомарганеи; d) марганеи металлический. о - среднемировые цены экспорта, $\diamond-$ импорт в Россию, 口-экспорт из России

Fig. 6. Dynamics of prices for manganese products for 1996-2018. Based on the data [7-9]: a) manganese ores and concentrates; b) ferromanganese; c) silicomanganese; d) manganese metal. $\diamond-$ world average export prices, $\diamond-i m$ port to Russia, $\square-$ export from Russia 
Дефицит потребления ферромарганца перекрывается импортом из Украины, Норвегии, а также из Франции и Южной Кореи (рис. 5, b). В целом его объемы импорта имеют четко выраженную тенденцию к снижению со 150 тыс. т в 1998 г. до 22 тыс. т в 2018 г. со среднегодовым понижением объемов $7,8 \%$. Он сопровождался снижением поставок с Украины (со 100 тыс. т в 2003 г. до 13 тыс. т в 2014 г., а также прекращением в 2015 г. импорта из Франции).

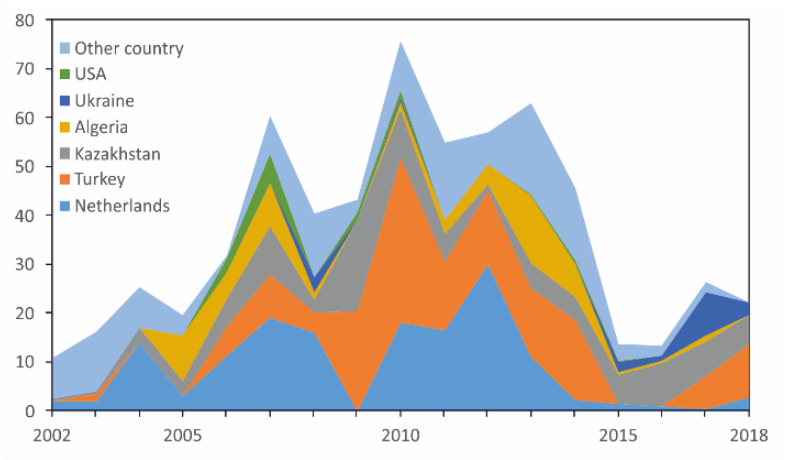

$a$
Доля импорта ферромарганца упала с 57-77 \% в 1996-2004 гг. до 10 \% в 2018 г. (рис. 4), т. е. этот минеральный продукт вышел из категории высокой импортозависимости в статус импортной независимости [16].

Экспорт ферромарганца (до 75 тыс. т в 2010 г.) осуществлялся в основном в Нидерланды, Турцию, Казахстан и Алжир, а также в виде встречных потоков - на Украину (рис. 7, a). Объемы экспорта и состав контрагентов покупки определялись текущей рыночной ситуацией и крайне неупорядочены.

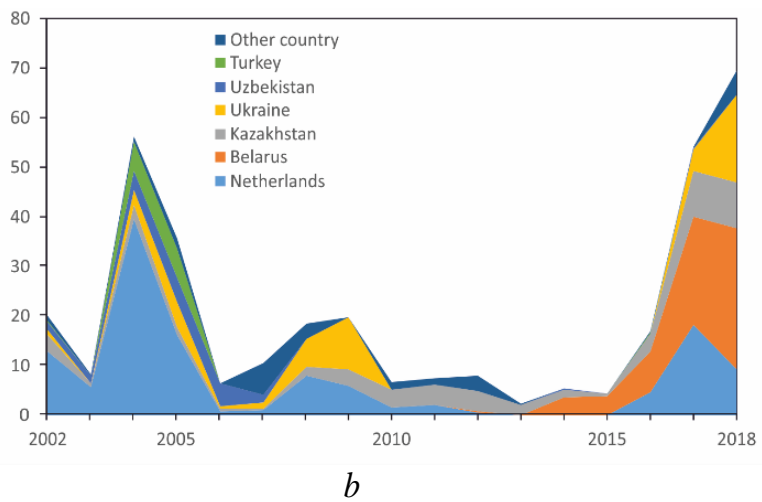

Рис. 7. Динамика объемов экспорта ферромарганиа (a) и силикомарганияа (b) по странам-покупателям за 2002-2018 г2., тыс. т. Составлено по данным Федеральной таможенной службы России [8]

Fig. 7. Dynamics of exports of ferromanganese (a) and silicomanganese (b) in importing countries for 2002-2018, thousand tons. Based on the data [8]

Стоимость годового импорта ферромарганца составляла 51-86 млн \$ США в 1996-2007 гг., ажиотажный всплеск в 108 млн \$ США в 2008 г., 55-80 млн \$ США/год в 2009-2013 гг. и падение до 27 млн \$ США в 2018 г. (рис. 3, a). Доля стоимости ферромарганца в 1996-2002 гг. от суммы стоимости марганцевых продуктов составляла 25-50\%, но в дальнейшем она начала снижаться, вплоть до 3,5 \% в 2018 г. (рис. 3, b).

Динамика мировых цен на ферромарганец (рис. $6, b$ ) включает следующие события: стабильный уровень 425-530 \$ США/т в период 1996-2003 гг.; рост цен в 2003-2008 гг. до аномального уровня в 2105 \$ США/т (начался ранее роста цен на марганцевые руды); резкий спад цены в 2009 г. до 1245 \$ США/т и тренд падения цен в 2010-2016 до 730 \$ США/т. В 2017 г. начался новый рост цен на ферромарганец - до 1330 \$ США/т. Российские цены импорта ферромарганца в периоды 1996-2003 и 2013-2017 гг. были несколько выше (5-15 \%) среднемировых экспортных цен, но в период неупорядоченности цен 2004-2012 гг. - на 10-50 \% ниже мировых. Экспортные российские цены практически повторяют тренд среднемировой экспортной цены, но ниже их на 5-10 \%, а по отношению к российским ценам импорта в период неупорядоченности цен 2004-2012 гг. - на 16-85 \% выше их уровня, а начиная с 2013 г. - на $10-15 \%$ ниже.

На фоне снижения объемов импорта ферромарганца начиная с 2002 г. появился встречный поток российского экспорта этого ферросплава (до 60 тыс. т [38 \% от производства] в 2007 г.) [18]. В результате этого возник искусственный дефицит ферромарганца для компенсации экспортного потока. Появился формальный нетто-экспорт ферромарганца, максимально составивший 41,4 тыс. т (191\% от импорта и $19 \%$ от потребления) в 2018 г. (рис. 8, a). Причиной возникновения встречных импортно-экспортных потоков являются собственные коммерческие интересы независимых ферросплавных заводов, рассматривающих рынок ферросплавов шире национальных интересов производства стали и находящих большую выгоду от экспортных поставок.

В динамике рынка силикомарганца (рис. 2, c) его производство имеет тенденцию к росту с 50 тыс. т (20\% от национального потребления) в 1997 г. до 353 тыс. т в 2018 г. (46 \% от потребления) со среднегодовым приростом +9,3%. В 2003-2006 гг. имело место уменьшение производства силикомарганца без снижения его потребления ввиду падения мировых цен на этот продукт. Потребление силикомарганца растет со 170 тыс. т в 1998 г. до максимума 497 тыс. т в 2007 г., просаживается во время кризиса 2008 г. до 368 тыс. т, в дальнейшем же составляет 410-460 тыс. т/год. Среднегодовой рост потребления ферросилиция составил $+3,7 \%$.

Импорт силикомарганца (рис. 4, c) в период низких цен на него, до 2007 г., имел тенденцию роста (с 115 до 430 тыс. т/год со среднегодовым ростом $+6,9$ \%), начиная с 2008 г. объемы импорта снизились, до 167 тыс. т в 2017 г. со среднегодовым темпом изменения объемов в $-9,2 \%$. Но в целом среднегодовые изменения импорта силикомарганца за 1996-2018 гг. составили $-1,1 \%$. 

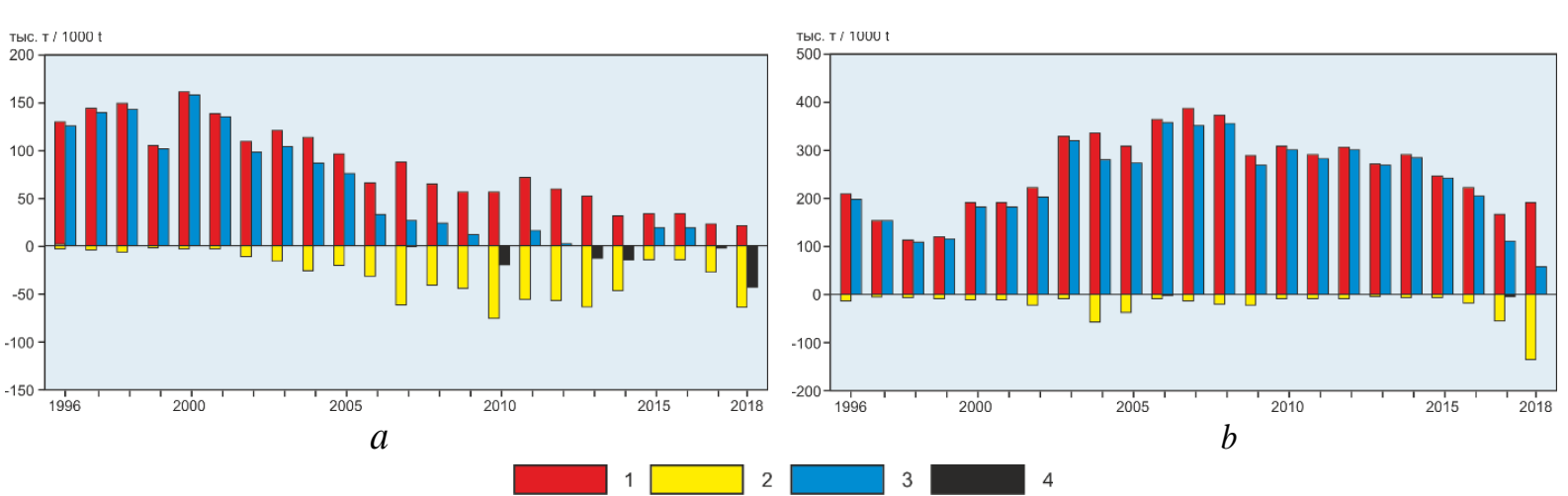

Рис. 8. Динамика объемов нетто-импорта и нетто-экспорта ферромарганца (а) и силикомарганцуа (b) за 1996-2018 г2.: 1 -uмnорт, 2 - экспорт, 3 -нетто-импорт, 4-нетто-экспорт

Fig. 8. Dynamics of volumes of net imports and net exports of ferromanganese (a) and silicomanganese (b) for 1996-2018: 1 - import, 2 - export, 3 - net import, 4-net export

Стоимость импортного потока силикомарганца в 1999-2003 гг. составляла 60-120 млн \$ США/год, с 2004 г. начался ее рост до максимума в 641,5 млн \$ США в 2008 г., после чего началось снижение импорта на фоне высоких цен, что и привело к падению стоимости импорта вплоть до 160-220 млн \$ США/год к 2016-2018 гг. (рис. 3, а). Доля стоимости импорта силикомарганеца наибольшая среди марганцевых продуктов (в среднем 49,5 \%), в 2004-2008 гг. она достигала 60-64 \%, но в дальнейшем доля стоимости начала снижаться вплоть до 29,5 \% в 2018 г. (рис. 3, $b$ ).

Поставки силикомарганца осуществлялись преимущественно с Украины (до 240 тыс. т/год), но с 2014 г. они начали сокращаться и в 2017 г. прекратились (рис. 5, c). Замещение выбывшего потока этого ферросплава компенсировалось увеличением поставок из Казахстана и, особенно, из Грузии (до 114 тыс. т/год).

Экспорт силикомарганца (2-66 тыс. т/год или 1-22\% от производства) неоднороден во времени, наибольшие поставки осуществлялись преимущественно в Нидерланды и Беларусь, а также встречный поток в Казахстан (рис. 7, b). Всплески объемов экспорта силикомарганца в 2004-2005 и 2017-2018 гг. (до $75 \%$ от производства) обусловлены высокими мировыми ценами на него в эти периоды.

Как и в случае с ферромарганцем для силикомарганца появился встречный экспортный поток: в 2002-2009 гг. - от 10 до 56 тыс. т/ год (20-75\% от производства), а в 2016-2018 гг. - до 133 тыс. т/год (15-37 \% от производства). Тем не менее отрицательный нетто-экспорт ни разу не возник, лишь неттоимпорт иногда уменьшается до $29 \%$ от объемов импорта или 14 \% от потребления (2018 г.) (рис. 8, b).

Динамика мировых цен на силикомарганец (рис. 6, c) включает следующие события: стабильный уровень 410-550 \$ США/т в 1996-2002 гг.; рост цен в 2003-2008 гг. до аномального уровня в 1772 \$ США/т; резкий спад цены в 2009 г. до 978 \$ США/т, затем стабилизация цен на уровне 1030-1170 \$ США/т в 2010-2018 гг. с просадкой в 2016 г. до 730 \$ США/т. Российские цены импорта силикомарганца в 2002-2014 гг. были ниже среднемировых, иногда на 20-25 \% (2003-2004 гг.), но начиная с 2015 г. стали их превышать на 10-18 \%. Цены экспорта силикомарганца были преимущественно выше его импортных цен: в 2000-2003 гг. - на 10-20\%, в 2004-2016 гг. на 20-40 \%. В 2017-2018 гг. цены экспорта и импорта силикомарганца примерно равны.

Доля импорта силикомарганца находилась на уровне 65-74 \% в 1996-2002 гг., на уровне 81-88 \% в 2003-2008 гг., а с 2009 г. началось ее падение до $36 \%$ в 2017 г. (рис. 4).

В анализируемом периоде наблюдается прогрессирующий рост потребления марганца металлического (рис. 2, d) с 4 тыс. т в 2000 г. до 68 тыс. т в 2018 г. со среднегодовыми темпами роста $+12,2 \%$. В России металлический марганец в промышленных масштабах в настоящее время не производится и полностью обеспечивается импортными поставками. Стоимость импортного потока марганца металлического увеличилась с 4 млн \$ США в 2000 г. до 151 млн \$ США в 2018 г. (рис. 3, a). Доля стоимости импорта марганца металлического от стоимости марганцевых продуктов также увеличилась с 1,9 \% в 2000 г. до 19,6 в 2018 г. (рис. 3,b).

Импорт марганца металлического осуществлялся преимущественно из Китая (до 63 тыс. т/год), (рис. 5, d). Экспорт марганца металлического отсутствует.

В динамике стоимости импорта металлического марганца имеется тенденция роста с 1-4 млн \$ США/год в 1996-2000 гг. до 130 млн \$ США в 2017 г., со среднегодовым ростом $+18,4$ \%/год (рис. $3, a$ ).

Динамика мировых цен на металлический марганец (рис. 6, d) включает тренд падения с 1770 \$ США/т в 1996 г. до 1110 \$ США/т в 2003 г.; рост цен до 3210 \$ США/т в 2011 г. (с аномальным всплеском до 3660 \$ США/т в 2008 г.) и тренд падения цен вплоть до минимума 2117 \$ США/т в 2016 г. Цены импорта металлического марганца были значительно ниже мировых, но в последние годы они выросли до равенства с последними.

В целом можно констатировать, что марганцевый концентрат и металлический марганец являются полностью импортозависимыми продуктами, силикомарганец - умеренно импортозависимым, а ферромарганеи - импортонезависимым (рис. 4) [16]. Но в целом динамику импортозависимости суммы всех 
видов марганцевого сырья можно оценить, приведя их данные в пересчете на условный продукт - $100 \%$ марганца (рис. 9). Как видно из динамики суммы всех видов марганцевого сырья, его производство имеет тенденцию к росту $+7,5 \% /$ год при росте потребления в $+3,9 \% /$ год. Объемы импорта также имеют среднегодовой рост $+3,3 \%$. Доли импорта от потребления и от реализации составляют от 66 до 86 \%, при небольшой тенденции к падению $(-0,5 \%$ отн/год). Таким образом, марганцевое сырье в сумме всех видов является значительно импортозависимым. На экспорт отправляется от 4 до $35 \%$ оперируемых объемов суммы марганцевых продуктов с тенденцией к увеличению $(+12,0 \%$ отн/год).

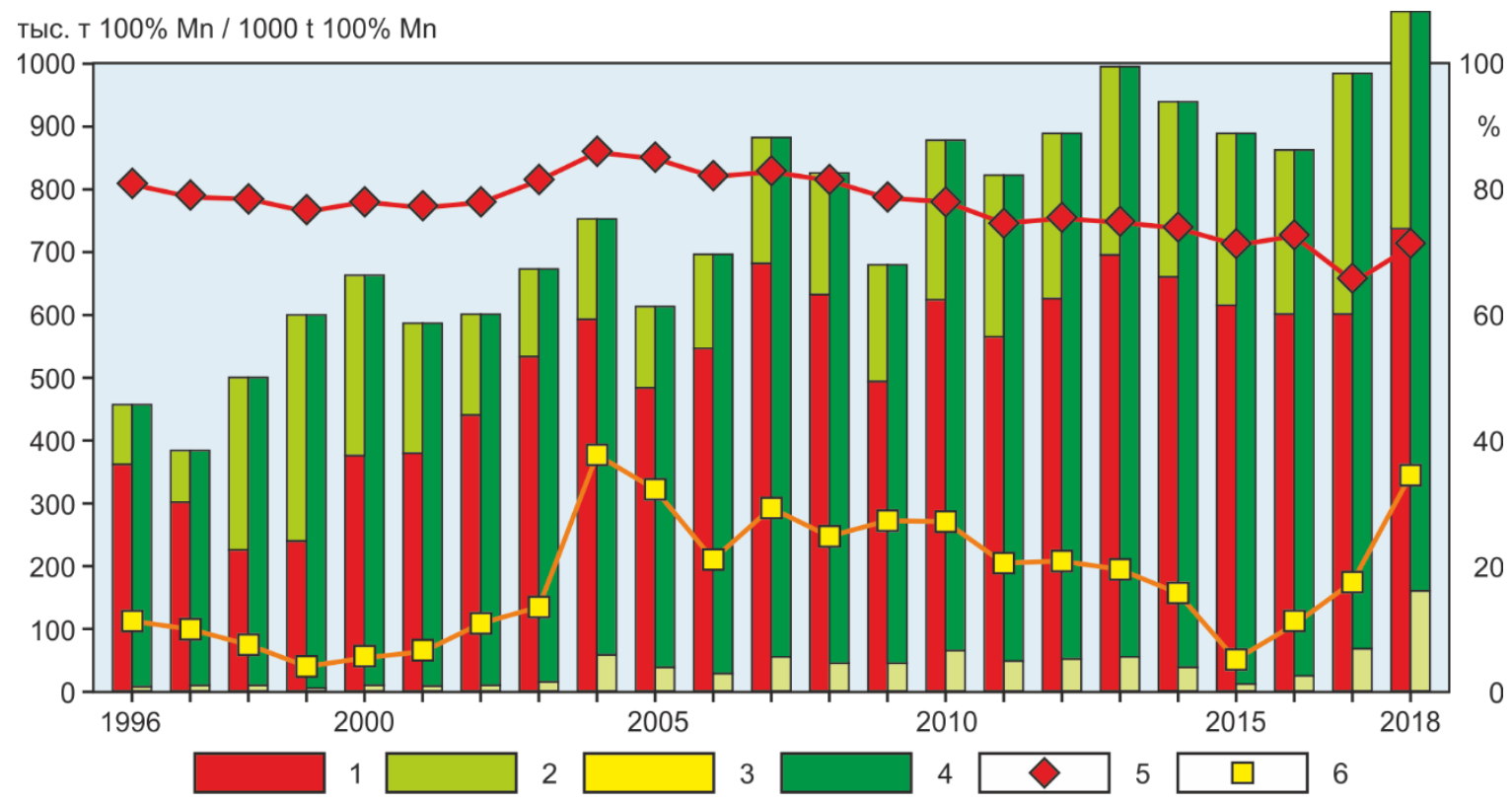

Pис. 9. Динамика объемов суммы марганиевых продуктов (в пересчете на $100 \%$ Мn) в России и долей их импорта и экспорта за 1996-2018 гг.: 1 - импорт, 2 - производство, 3 - экспорт, 4 -нетто-потребление, 5 - доля импорта от потребления, 6 - доля экспорта от производства

Fig. 9. Dynamics of volume of manganese amount products (in recalculation on $100 \% \mathrm{Mn}$ ) in Russia and the share of imports and exports for 1996-2018: 1 - import, 2 - manufacturing, 3 - exports, 4 - net consumption, 5 - import share of consumption, 6 - export share of production

По состоянию на 2017 г. на импорт приходится 100 \% потребления марганцевых руд и концентратов (1318 тыс. т на сумму 365 млн \$ США), $19 \%$ - ферромарганца (21 тыс. т на сумму 27 млн \$ США), $46 \%$ - силикомарганца (192 тыс. т на сумму 227 млн \$ США) и $100 \%$ - марганца металлического (68 тыс. т на сумму 151 млн \$ США). Стоимость потока суммы марганцевых продуктов медленно растет во времени с 163 млн \$ США в 1999 г. до 338 млн \$ США в 2006 г., в кризисный 2008 г. достигает 1113 млн \$ США, затем провал до 464 млн \$ США в 2009 г., в 2010-2018 гг. суммарная стоимость годового потока марганцевого сырья составляла 585-625 млн \$ США с кризисным максимумом в 2008 г. (рис. 3, a). Среднегодовой рост стоимости суммы импорта марганцевых продуктов за 1996-2018 гг. составил +6,9%/год.

Таблица. Темпы среднегодичных изменений показателей товарных потоков марганцевого сырья за 1996-2018 гг., \% отн./год.

Table. Rates of average annual changes in indicators of commodity flows of manganese raw materials for 1996-2018, \%.

\begin{tabular}{|c|c|c|c|c|c|}
\hline $\begin{array}{l}\text { Параметры } \\
\text { Parameters }\end{array}$ & $\begin{array}{c}\text { Марганцевые } \\
\text { руды } \\
\text { Manganese ore } \\
\end{array}$ & $\begin{array}{l}\text { Ферромарганец } \\
\text { Ferromanganese }\end{array}$ & $\begin{array}{l}\text { Силикомарганец } \\
\text { Silicomanganese }\end{array}$ & $\begin{array}{c}\text { Марганец } \\
\text { металлический } \\
\text { Metal manganese }\end{array}$ & $\begin{array}{c}\text { Сумма марганцевых } \\
\text { продуктов } \\
\text { Sum of manganese products }\end{array}$ \\
\hline $\begin{array}{l}\text { Объемы производства } \\
\text { Production volume }\end{array}$ & - & $+6,5$ & $+9,3$ & - & $+7,5$ \\
\hline $\begin{array}{l}\text { Объемы импорта } \\
\text { Volume of imports } \\
\end{array}$ & $+7,4$ & $-7,8$ & $\begin{array}{c}-0,4 \\
(2008-2018 \text { гг. }-7,2) \\
\end{array}$ & $+12,2$ & $+3,3$ \\
\hline $\begin{array}{l}\text { Объемы потребления } \\
\text { Volume of consumption }\end{array}$ & $+7,2$ & $+0,6$ & $+5,3$ & $+12,2$ & $+3,9$ \\
\hline $\begin{array}{l}\text { Цена импорта } \\
\text { Imports price } \\
\end{array}$ & $+16,0$ & $+5,5$ & $+4,6$ & $+8,2$ & - \\
\hline $\begin{array}{l}\text { Стоимость импорта } \\
\text { Cost of imports }\end{array}$ & $+15,1$ & $-4,4$ & $+2,8$ & $+18,4$ & $+6,9$ \\
\hline $\begin{array}{l}\text { Доля импорта } \\
\text { Share of imports }\end{array}$ & $+0,2$ & $-3,9$ & $-2,0$ & - & $-0,5$ \\
\hline
\end{tabular}


По темпам изменений показателей товарных потоков марганцевого сырья за 1996-2018 гг. (таблица):

- максимальный рост темпов объемов потребления ожидаемо имеет место для марганца металлического $(+18,4 \% /$ год), но его доля в общем потреблении марганцевых продуктов в 2018 г. составляет всего $6,1 \%$;

- максимальный рост цены импорта наблюдается для марганцевых руд и концентратов $(+16,0 \%)$, а т. к. они составляют основную долю марганцевых продуктов (51,3 \% в 2018 г.), то на них и приходится большая часть стоимости суммарного импорта (рис. 3) и рост темпов объемов импорта и потребления выше среднего по всем марганцевым продуктам;

- темпы снижения объемов импорта ферромарганца $(-7,8 \%)$ выше темпов увеличения его производства $(+6,5 \%)$, что и позволило перевести этот товарный продукт из полностью импортозависимового в импортонезависимую категорию;

- темпы роста объемов производства силикомарганца выше средних по марганцевым продуктам (+9,3\%>+7,5\%), но снижение темпов объемов импорта небольшие $(-0,4 \%)$, т. е. ситуация с импортозамещением главного марганцевого ферросплава остается неопределенной.

\section{Пути решения проблемы дефицита} марганцевого сырья

Предполагается, что к 2030 г. потребление марганцевой продукции в результате дальнейшего развития российской сталелитейной промышленности может вырасти на 50 \% [19]. Поэтому в ближайшем будущем черная металлургия страны не сможет обойтись без импорта марганцевого сырья и продукции, однако требуется серьезное упорядочение и стабилизация импортных поставок марганцевого концентрата и ферросплавов [20].

Решение проблем марганцевого импортного сырья возможно в следующих направлениях:

1. Поиски и освоение новых промышленно значимых месторождений высококачественного марганцевого сырья.

2. Разработка и внедрение новых технологий добычи и обогащения марганцевых руд, а также производства марганцевых ферросплавов.

3. Стабилизация импортных поставок марганцевого сырья.

1. Поиски и освоение новых месторождений марганца. Месторождения марганца на территории России [21] ввиду наличия на территории СССР уникальных никопольских месторождений на юге Украины и месторождений высококачественных руд в Грузии, исследовались ранее по остаточному принципу - проявления и месторождения марганцевых руд фиксировались, изредка оценивались, крайне редко разведывались и разрабатывались. Лишь во время Великой Отечественной войны были интенсифицированы работы по изучению марганцевых месторождений Урала, Сибири и Дальнего Востока, было разведано Усинское месторождение в Кемеровской области, разрабатывалось Мазульское месторождение в Красноярском крае. К настоящему времени на территории России известно более 50 месторождений марганца, из которых периодически разрабатывались Парнаокское, Тыньинское, Дурновское и Громовское месторождения. Разработка и внедрение новых ресурсо- и энергосберегающих технологических схем обогащения руд и получения марганцевых сплавов (включая ферросплавы из бедного и фосфорсодержащего сырья) может позволить отрабатывать уже подготовленные месторождения (крупнейшие в России) - Усинское в Кемеровской области, ЮжноХинганского в Еврейской АО и Порожинское в Красноярском крае (рис. 1).

Крупнейшее в России Усинское месторождение в Кемеровской области представлено в основном карбонатными рудами (свыше 120 млн т руды или 23 млн т $100 \% \mathrm{Mn})$, вследствие чего оператор проекта разработки ЧЕК-СУ ориентируется на переработку этих руд на металлический марганец на базе Туимского завода цветных металлов в Республике Хакассия с годовым выпуском до 70 тыс. т, что перекроет национальную потребность в этом продукте [6, 22, 23].

Южно-Хинганское месторождение преимущественно оксидных руд (8 млн т руды или 1,6 млн т $100 \% \mathrm{Mn})$, расположенное в Еврейской ОА, подготавливается к освоению китайской компанией ООО «Хэмэн Дальний Восток», планируемые объемы годовой добычи марганцевой руды - до 300 тыс. т [6]. Но товарный поток с этого месторождения, скорее всего, пойдет в Китай - более удобный по логистике потребитель марганцевого сырья.

Порожинское месторождение в Красноярском крае является крупнейшим из подготовленных в России месторождений оксидных руд (29 млн т руды или 5,5 млн т $100 \%$ Mn) [24], но оно расположено вне доступной транспортной инфраструктуры. Осуществлялись попытки его освоения (ООО «Туруханский меридиан»), но до начала выпуска товарной руды дело так и не дошло.

Суммарные подготовленные запасы марганцевого сырья в России составляют 232,8 млн т $\left(\mathrm{A}+\mathrm{B}+\mathrm{C}_{1}+\mathrm{C}_{2}\right)$, но большая их часть приходится на бедные и технологически сложные руды, а многие месторождения находятся далеко от развитой транспортной инфраструктуры [6]. Тем не менее обнаружение новых марганцевых месторождений в связи с относительно слабой опоискованностью территорий на марганец возможно практически во всех марганцевоносных провинциях России, но предпочтительнее все же находки в районах с развитой инфраструктурой - в СевероКавказской [2], Южно-Уральской [25], СреднеУральской [26], Полярно-Уральской [27], СалаироКузнецкой и Енисейской [28], Прибайкальской [2], Забайкальской [29], Хинганской и Средне-Амурской [30] провинциях. Интерес для поисков должны представлять крупные месторождения высококачественного сырья близ имеющихся транспортных коммуникаций. 
Вторым возможным направлением пополнения минерально-сырьевой базы марганца России является вовлечение в производство месторождений железомарганцевых конкреций глубоководного дна Мирового океана [31-33]. В Тихом Океане, в рудном поле Кларион-Клипперон, за Россией Международным органом по морскому дну (МОД) при ООН закреплен участок морского дна для разведки и добычи железомарганцевых конкреций площадью 75 тыс. км² со средней плотностью конкреций 50-70 кг/м², содержащих в среднем 29,4\% Mn. Помимо этого, Российская Федерация является участником совместной организации Interoceanmetal Joint Organization (IOM) (Болгария, Куба, Чехия, Польша, Россия, Словакия), которой также выделен участок с месторождением железомарганцевых конкреций в этой же зоне Кларион-Клиппертона. Уже осуществлены пробные отработки морского дна, подтверждающие техническую возможность и экономическую рентабельность этих проектов. Минимально промышленная концентрация железомарганцевых конкреций на морском дне определена в $5 \mathrm{\kappa r} / \mathrm{m}^{2}$. По первому участку морского дна России предоставлена квота годовой добычи до 3,5 млн т конкреций в год, что эквивалентно выпуску до 1 млн т марганцевых ферросплавов. Однако до сих пор проекты разработки минеральных ресурсов морского дна остаются малопривлекательными для инвесторов ввиду высоких рисков их осуществления:

- при отсутствии опыта промышленной разработки минеральных ресурсов глубинного морского дна в реальных условиях, с обеспечением непрерывности и равномерности сбора железомарганцевых конкреций, их подъема на морские суда, перегрузки на транспортные суда, особенно при неблагоприятной метеообстановке в районе разработок;

- технологических сложностях переработки железомарганцевых конкреций на товарные марганцевые продукты ввиду наличия попутных полезных компонентов, подлежащих извлечению для последующей реализации;

- необходимости выплаты кроме национальных налогов дополнительного налога в пользу Международного органа по морскому дну или International Seabed Authority (МОМД или ISA) $\mathrm{OOH} \mathrm{(ст.} 13$ прил. III «Конвенции ООН по морскому праву» [34]).

Тем не менее в настоящее время 13 организаций Китая, Японии и России проводят работы по оценке и опытно-промышленной эксплуатации месторождений железомарганцевых конкреций на участках морского дна, закрепленных за этими странами [3].

Принципиальное решение по освоению месторождений железомарганцевых конкреций дна Мирового океана полностью бы закрыло проблему импортных поставок марганцевого сырья в Россию, но такое возможно только в рамках крупного национального проекта в условиях достаточности финансирования инвестиций.

2. Разработка новых технологий. Сокращение ресурсов богатых марганцевых руд привело к необхо- димости обогащения бедных их разностей до товарного вида - марганцевого концентрата. Необходимо получение товарного продукта, содержащего свыше $34 \% \mathrm{Mn}$ (I сорт - не менее $43 \% \mathrm{Mn}$ ), с отношением $\mathrm{Mn} / \mathrm{Fe}>7$ и отношением $\mathrm{P} / \mathrm{Mn}<0,0035$. Главный показатель - содержание $\mathrm{Mn}$ в концентрате и его повышение на $1 \%$ эквивалентно экономии 40 кВт-ч. Используются традиционные схемы мокрой гравитационной и магнитной сепарации, флотации шламов, а также новые - получение синтетического пиролюзита хемосорбционного концентрата оксида марганца.

Применение новых методов обогащения может позволить получать из труднообогатимых руд товарные марганцевые концентраты с более низким уровнем издержек и получением более качественных продуктов. К ним следует отнести:

- энергоэкономные способы обогащения минерального сырья: рентгенорадиометрический (РРМ), фотометрический $(Ф \mathrm{M})$ и рентгенолюминесцентный (РЛМ). ФМ испытан на рудах Никопольского месторождения, сочетание РРМ и ФМ - на рудах Тыньинского месторождения, РРМ - на предварительной сортировке руд Порожинского месторождения [35-37];

- использование при магнитной сепарации энергоэкономных высокоградиентных постоянных магнитов [36];

- химическое выщелачивание марганца из недробленных бедных руд [37-39];

- биовыщелачивание марганца из шламов и отвалов обогащения [40];

- производство синтетического марганцевого сырья (синтетического пиролюзита) [41].

Возможно использование в разработке марганцевых и новых горных технологий:

- скважинная гидродобыча рыхлых марганцевых руд [42];

- подземное химическое [37, 38] и бактериальное [40] выщелачивание марганца из глубоких (недоступных) горизонтов марганцевых руд.

При переработке марганцевых руд на ферросплавы также возможно применение новых материало- и энергосберегающих технологий:

- передел на ферросплавы бедных марганцевых руд [43-46];

- производство ферросплавов из карбонатных марганцевых руд [23, 38];

- гидрометаллургические [46] и газовые [47] технологии производства ферросплавов;

- снижение вредных примесей в марганцевых ферросплавах [48];

- снижение энергоемкости ферросплавной продукции [49];

- производство новых видов марганцевых ферросплавов [50].

Таким образом, имеются все предпосылки для снижения издержек производства добычи и обогащения руд марганцевых месторождений, а также выпуска марганцевых ферросплавов. 
3. Стабилизаиия импортных поставок. В ближайшее время вряд ли возможно существенное замещение импортных поставок марганцевого сырья. Поэтому проблеме их стабилизации следует уделить главное внимание.

Основными поставщиками марганцевого концентрата в Россию является казахстанские предприятия - Жайремский ГОК и рудник Джезды, управляемый холдингом «Казахмарганец». Поставщиками ферросплавов являются Никопольский и Запорожский ферросплавные заводы с Украины, казахстанские ферросплавные заводы «Аксу» и «Феррохром» холдинга «Казхром», Зестафонский завод ферросплавов в Грузии, ферросплавные заводы в г. Саннефьорде (Норвегия) и г. Дюнкерк (Франция). Казахстанские источники марганцевого сырья предпочтительны в части относительной дешевизны поставляемых продуктов, отсутствии взимания ввозной пошлины (как страны Таможенного Союза) и небольших транспортных расходов по доставке материалов к месту потребления. Этот устойчивый транспортный поток марганцевого концентрата следует поддерживать, в том числе и на государственном уровне. Например, через механизм регулирования цен естественных монополий (ОАО «Российские железные дороги») государство имеет возможность установить регулируемые тарифы на перевозку этого дефицитного сырья.

Углубление экономических связей стран БРИКС способствовало появлению на российском рынке нового потока марганцевого сырья от мирового лидера добычи марганцевых руд - Южно-Африканской Республики [51], а также из Габона с его месторождений высококачественных марганцевых руд. Российская группа компаний «Ренова» создала в ЮАР консорциум United Manganese of Kalahari (UMK) для совместной разведки, добычи и переработки марганцевых руд (доля ГК «Ренова» - 49 \%). Объемы добычи марганцевых руд этого предприятия на рудном поле Калахари превышает 3 млн т/год, и до 500 тыс. т/год экспортируется в Россию. Следует также поддерживать стабильность поставок из этого источника.

\section{Выводы}

1. Импортозависимость по марганцевым рудам по состоянию на 2018 г. составляет $100 \%$ от потребления (импортировано 1318 тыс. т), по силикомарганцу $-46 \%$ (импорт 192 тыс. т), по марганцу металлическому - $100 \%$ (импорт 68 тыс. т) и по ферромарганцу - $10 \%$ (импорт 21 тыс. т). Суммарно в 2018 г. импортировано 1,6 млн т марганцевых продуктов, что составляет $72 \%$ от их потребления. Среднегодовое снижение доли импорта в потреблении суммы марганцевых продуктов в 1996-2018 гг. составляло всего -0,5\%/год, при этом доля импорта марганцевых руд и концентратов росла с темпами $+0,2 \% /$ год.

2. Марганщевые руды и концентраты являются абсолютно импортозависимым товарным продуктом (100\% импорта от потребления). Даже ввод в эксплуатацию крупнейшего в России Усинского месторождения решит проблему обеспечения лишь $12 \%$ марганцевого ферросплавного производства. Порожинское месторождение находится вне доступной транспортной инфраструктуры и вряд ли в ближайшем будущем будет освоено. Не наблюдается и новых открытий в поисках месторождений марганцевого сырья. Потребление марганцевого концентрата увеличилось с 285 тыс. т в 1996 г. до 1,3 млн т в 2018 г. (+7,2 \%/год). В ближайшем будущем черная металлургия страны не сможет обойтись без импорта марганцевого концентрата, и поэтому требуется серьезное упорядочение импортных поставок марганцевого концентрата, стабилизация их потоков, как традиционного - из Казахстана (в рамках Таможенного союза), так и от новых странпартнеров - Южно-Африканской Республики (в рамках союза стран БРИКС) и Габона. Стабилизации надежного импорта в Россию марганцевого сырья способствуют и российские инвестиции в зарубежные марганцедобывающие и ферросплавные предприятия.

3. Национальное потребление силикомарганца увеличилось с 170 тыс. т в 1998 г. до 455 тыс. т в 2017 г. (+5,3\%/год), а производство возросло с 50 до 355 тыс. т/год (+6,5\%/год). Тем не менее объемы импорта силикомарганца остались на прежнем уровне - 170-190 тыс. т/год, а в 2003-2008 гг. они составляли 310-435 тыс. т/год, т. е. начиная с 2008 г. темпы снижения объемов импорта силикомарганца составляли $-7,2 \% /$ год. Сократившийся импорт с Украины замещен поставками из Грузии, Казахстана и Норвегии. Но пока еще силикомарганец является импортозависимым товаром.

4. Национальное потребление ферромарганца увеличилось незначительно - с 193 тыс. т в 1996 г. до 262 тыс. т в 2017 г. (+0,6 \%/год), причем объемы производства резко возросли с 50 до 260 тыс. т/год (+6,5 \%/год). Объемы импорта ферромарганца при этом серьезно сократились с 130 до 21 тыс. т/год $(-3,9 \% /$ год). Поэтому ферромарганец за последние годы вышел из полной импортной зависимости в импортонезависимую категорию.

5. Появился спрос на новый товарный продукт - марганец металлический, потребление которого выросло с 0,3 тыс. т в 1996 г. до 68 тыс. т в 2018 г. $(+12,2 \% /$ год). В настоящее время потребность в нем покрывается за счет импорта. После ввода в эксплуатацию Усинского месторождения и Туимского завода производство металлического марганца полностью перекроет национальное потребление.

6. На фоне тотального импорта марганцевых ферросплавов появилось явление встречной импортноэкспортной торговли (экспорт до 63 тыс. т/год ферромарганца и до 133 тыс. т/год силикомарганца), вплоть до формирования направления нетто-экспорта ферромарганца до 41 тыс. т/год ферромарганца.

7. Первоочередные поиски новых месторождений марганца предпочтительно организовывать на недостаточно исследованных территориях вдоль новых железнодорожных магистралей (БайкалоАмурской и Амуро-Якутской) в пределах Прибайкальской, Забайкальской и Усть-Майской марганценосных провинций. 


\section{СПИСОК ЛИТЕРАТУРЫ}

1. Марганец. Минерально-сырьевая база СНГ. Добыча и обогащение руд / К.Н. Трубецкой, В.А. Чантурия, А.Е. Воробьёв, Л.П. Тигунов. - М.: Изд-во Академии горных наук, 1999. $271 \mathrm{c}$.

2. Тигунов Л.П. Состояние и перспективы развития сырьевой базы черной металлургии. Марганцевые руды // Минеральные ресурсы России. Экономика и управление. - 1994. - № 4. C. $14-19$.

3. Critical mineral resources of the United States - economic and environmental geology and prospects for future supply / K.J. Schulz, J.H. DeYoung, R.R. Seal, D.C. Bradley. - Reston: U.S. Department of the Interior; U.S. Geological Survey. - 2017. 862 p. URL: https://pubs.usgs.gov/pp/1802/pp1802_entirebook.pdf (дата обращения: 06.10.2019).

4. Study on the review of the list of critical raw materials. Critica raw materials factsheets / Written by Deloitte Sustainability; British Geological Survey; Bureau de Recherches Géologiques et Minières; Netherlands Organisation for Applied Scientific Research. - 2017. - 515 p. URL: https://publications.europa.eu/en/ publication-detail/-/publication/7345e3e8-98fc-11e7-b92d01aa75ed71a1 (дата обращения: 06.10.2019).

5. Public annual market research report [Manganese] // International Manganese Institute (IMI). 2016. 92 p. URL: https://www. manganese.org/files/publications/PUBLIC\%20RESEARCH\%20R EPORTS/2013_IMnI_Public_Report.pdf (дата обращения: 06.10.2019)

6. Государственный доклад «О состоянии и использовании минерально-сырьевых ресурсов Российской Федерации в 2016 2017 годах». URL: http://www.mnr.gov.ru/docs/o_sostoyanii_i ispolzovanii_mineralno_syrevykh_resursov_rossiyskoy_federatsii/ gosudarstvennyy_doklad_o_sostoyanii_i_ispolzovanii_mineralno_ syrevykh_resursov_rossiyskoy_federatsii/_ (дата обращения 06.10.2019)

7. Федеральная служба государственной статистики России. URL: https://gks.ru/emiss (дата обращения: 06.10.2019).

8. Федеральная таможенная служба России. URL: http://stat.customs.ru/analytics/ (дата обращения: 06.10.2019).

9. Международная торговля товарами. TrendEconomy. URL: http://data.trendeconomy.ru/dataviewer/trade/statistics/ (дата обращения: 06.10.2019).

10. Информационно-аналитический центр «Минерал» URL http://www.mineral.ru/Center/index.html (дата обращения: 06.10.2019).

11. Tangstad M. Manganese ferroalloys technology (Book Chapter) Handbook of ferroalloys. - Oxford (UK); Waltham (USA): $\begin{array}{llll}\text { Butterworth-Heinemann, 2013. } & - & \text { P. 221-266. }\end{array}$ DOI: 10.1016/B978-0-08-097753-9.00007-1.

12. Колоскова И.С. Структура производства и рынок марганцевого сырья в России // Минеральные ресурсы России. Экономика и управление. - 2014. - № 1. - С. 74-77.

13. Polulyakh L.A., Dashevskii V.Y., Yusfin Y.S. Manganeseferroalloy production from Russian manganese ore // Steel in Translation. - 2014. - V. 44. - № 9. - P. 617-624. DOI: $10.3103 / \mathrm{S} 0967091214090125$.

14. Ferroalloy production in Russia / L.I. Leontev, V.I. Zhuchkov, A.V. Zhdanov, V.Y. Dashevskii // Steel in Translation. - 2015. V. 45. - № 10. - P. 773-777. DOI: 10.3103/S0967091215100101.

15. Лаптева А.М., Митрофанов Н.П., Тигунов Л.П. Минеральносырьевая база легирующих металлов: состояние, проблемы и перспективы освоения // Горный журнал. - 2017. - № 7 . C. 10-16. DOI: $10.17580 / \mathrm{gzh} .2017 .07 .02$.

16. Боярко Г.Ю., Хатьков В.Ю. Товарные потоки ферросплавов в России // Черные металлы. - 2018. - № 3. - С. 60-69.

17. Dashevskii V.Y., Zhuchkov V.I., Leontev L.I. Utilization of manganese in Russian metallurgy // Steel in Translation. - 2019. V. 49. - № 1. - P. 50-57. DOI: 10.3103/S0967091219010042.

18. Хатьков В.Ю., Боярко Г.Ю. Мировые и российские встречные импортно-экспортные потоки минерального сырья // Известия Томского политехнического университета. Инжиниринг георесурсов. - 2018. - Т. 329. - № 3. - С. 145-167.

19. Стратегия развития черной металлургии России на 2014-2020 годы и на перспективу до 2030 года / Утв. Приказом Минпромторга России от 05.05.2014 № 839. URL: https://www.garant.ru/products/ipo/prime/doc/70595824/ （дата обращения: 06.10.2019).

20. Ходина М.А. Российский рынок марганцевой продукции и потенциальные возможности ее импортозамещения // Разведка и охрана недр. - 2017. - № 2. - С. 42-48.

21. Марганцевое рудообразование на территории СССР / под ред. Д.Г. Сапожникова. - М.: Наука, 1984. - 280 с.

22. Вальщиков А.В., Литвиненко А.П., Делер М. Проект освоения Усинского месторождения марганца. Технология обогащения руды // Минеральные ресурсы России. Экономика и управление. - 2011. - № 3. - С. 80-83

23. Production of manganese ferroalloys from Usinsk manganese ore / V.Y. Dashevskii, Y.S. Yusfin, G.S. Podgorodetskii, N.V. Baeva // Steel in Translation. - 2013. - V. 43. - № 9. - P. 544-551. DOI: 10.3103/S0967091213090052.

24. Примак В.С., Небогов В.К., Спиридонова Е.Л. Перспективы освоения Порожинского месторождения марганца в Красноярском крае // Горный журнал. - 2006. - № 8. - С. 23-27.

25. Салихов Д.Н., Ковалев С.Г., Брусницын А.И. Полезные ископаемые Республики Башкортостан (марганцевые руды). Уфа: Институт геологии УНЦ АН Республики Башкортостан, 2002. $-243 \mathrm{c}$.

26. Контарь Е.С. Марганцевые месторождения Урала. - Екатеринбург: КПР по Свердловской области, 1999. - 118 с.

27. Марганцевоносность Полярного Урала / Б.Ф. Костюк, Л.А. Островский, В.Н. Пенчук, А.Л. Ильюшинов // Состояние марганцево-рудной базы России и вопросы обеспечения промышленности марганцем: Материалы первой научнотехнической конференции. - Екатеринбург: Изд-во Екатеринбургской ассоциации малого бизнеса, 2000. - С. 93-98.

28. Цыкин Р.А. Гипергенные марганцевые руды Центральной Сибири // Журнал Сибирского федерального университета. Серия: Техника и технологии. - 2008. - Т. 1. - № 1. - С. 3-16.

29. Вахрушев В.А., Павленко Ю.В. Читинская область - новая потенциальная марганцеворудная провинция России // Состояние марганцево-рудной базы России и вопросы обеспечения промышленности марганцем: Материалы первой научнотехнической конференции. - Екатеринбург: Изд-во Екатеринбургской ассоциации малого бизнеса, 2000. - С. 116-123.

30. Черепанов А.А. Марганцевые руды Дальнего Востока // Сoстояние марганцево-рудной базы России и вопросы обеспечения промышленности марганцем: Материалы первой научнотехнической конференции. - Екатеринбург: Изд-во Екатеринбургской ассоциации малого бизнеса, 2000. - С. 134-136.

31. Железомарганцевые образования мирового океана и морского шельфа - минеральное сырье многоцелевого назначения / Л.3. Быховский, Л.П. Тигунов, И.М. Мирчинк, В.Б. Терентьев // Минеральные ресурсы России. Экономика и управление. 2009. - № 2. - C. 17-24.

32. Metal extraction from deep-ocean mineral deposits / M.V. Zubkov, P.K. Plucinski, A.C.Y. Dartiguelongue, P.A.J. Lusty // Elements. 2018. - V. 14. - № 5. - P. 319-324. DOI: 10.2138/gselements.14.5.319.

33. Lusty P.A.J., Murton B.J. Deep-ocean mineral deposits: metal resources and windows into earth processes // Elements. - 2018. V. 14. - № 5. - P. 301-306. DOI: 10.2138/gselements.14.5.301

34. Конвенция ООН по морскому праву / Совершено в МонтегоБее 10 декабря 1982 г. (с изм. от 23.07.1994) // Бюллетень международных договоров. - 1998. - № 1. - С. 3-168.

35. Современные технологии в эффективном освоении и развитии МСБ твердых полезных ископаемых России / А.А. Рогожин, А.В. Темнов, Л.П. Тигунов, Н.В. Петрова, А.Д. Коноплев // Разведка и охрана недр. - 2006. - № 7. - С. 33-41.

36. Тигунов Л.П., Ожогина Е.Г., Литвинцев Э.Г., Броницкая Е.С., Ануфриева С.И., Калиш Е.А. Современные технологии обогащения и гидрометаллургического передела марганцевых руд // Горный журнал. - 2007. - № 2. - С. 78-84.

37. Chernobrovin V.P., Mizin V.G., Sirina T.P. Production of highquality manganese concentrates from carbonate ores // Steel. 2005. - № 1. - P. 53-55.

38. Комплексная переработка карбонатного марганцевого сырья: химия и технология / В.П. Чернобровин, В.Г. Мизин, Т.П. Сирина, В.Я. Дашевский. - Челябинск: ИЦ ЮУрГУ, 2009. $293 \mathrm{c}$.

39. Перспективы применения технологии кучного выщелачивания для переработки труднообогатимых марганцевых руд / 
В.Н. Соколова, С.И. Ануфриева, А.В. Темнов, О.С. Борзых, О.А. Якушина // Разведка и охрана недр. - 2011. - № 8. C. 44-49.

40. Das A.P., Ghosh S. Bioleaching of manganese from mining waste materials // Materials Today: Proceedings. - 2018. - V. 5. - № 1. P. 2381-2390. DOI: 10.1016/j.matpr.2017.11.459.

41. Zhukov D.Y., Averina Y.M. Development of a pyrometallurgical technology for processing synthetic pyrolusite and chemisorption manganese oxide concentrate into metallic manganese and lowcarbon ferroalloys // CIS Iron and Steel Review. - 2019. - V. 17. P. 25-29. DOI: 10.17580/cisisr.2019.01.04.

42. Комплексное освоение недр способом скважинной гидродобычи / В.И. Стрельцов, Ю.И. Волков, А.Г. Балашов, Т.П. Стрельцова // Горный журнал. - 2010. - № 7. - С. 33-36.

43. Improving manganese utilization in the production of manganese ferroalloys / V.Ya. Dashevskij, Yu.S. Yusfin, A.A. Aleksandrov, L.I. Leontev, G.S. Podgorodeckij, V.I. Gubanov // Steel in Translation. - 2013. - № 7. - P. 32-37. DOI: $10.3103 /$ S0967091213070036.

44. Complex processing of manganese bearing waste and low-grade ores by autoclaving method / A. Chirakadze, L. Gurchumelia I. Khomeriki, W.A. Toscano, I. Bazghadze, I. Geleishvili, V. Gvakharia, T. Geleishvili // International journal of global warming. - 2016. - V. 10. - № 1. - P. 291-306. DOI: 10.1504/IJGW.2016.077919.

45. Calculations of manganese ferroalloys production efficiency from different ores / V.I. Zhuchkov, A.V. Zhdanov, L.I. Leontev,
V.Y. Dashevskii // Steel in Translation. - 2016. - V. 46. - № 11. P. 814-817. DOI: 10.3103/S0967091216110139.

46. Zhukov D.Y., Averina Y.M., Menshikov V.V. Design of a hydrometallurgical complex for processing of complex low-grade manganese ores // CIS Iron and Steel Review. - 2018. - V. 16. P. 4-10. DOI: 10.17580/cisisr.2018.02.01.

47. Kinetics and mechanism of low-grade manganese ore reduction by natural gas / A. Cheraghi, H. Yoozbashizadeh, E. Ringdalen, J. Safarian // Metallurgical and Materials Transactions B: Process Metallurgy and Materials Processing Science. - 2019. - V. 50. № 4. - P. 1566-1580. DOI: 10.1007/s11663-019-01574-4.

48. Han P., Zhang G., Chu S. Reducing dephosphorization of silicomanganese ferroalloys by $\mathrm{CaO}-$ based slag // Metallurgical Research and Technology. - 2017. - V. 114. - № 6. - Article number 605. DOI: $10.1051 / \mathrm{metal} / 2017020$.

49. Tleugabulov S.M., Tazhiev E.B. Energy-saving ferroalloy production // Steel in Translation. - 2017. - V. 47. - № 10. P. 682-687. DOI: $10.3103 /$ S0967091217100102.

50. Silicomanganese production at mogale alloys / N.A. Sithole, N. Rambuda, J.D. Steenkamp, D.A. Hayman, C. Hockaday // Journal of the Southern African Institute of Mining and Metallurgy. 2018. - V. 118. - № 11. - P. 1205-1216. DOI: 10.17159/24119717/2018/v118n11a11.

51. Хмелевская Н.Г. Приоритеты внешнеторговой политики России в орбите экономического сотрудничества БРИКС // Экономическая политика. - 2015. - Т. 10. - № 2. - С. 93-109.

Поступила 14.11.2019 2.

\section{Информация об авторах}

Боярко Г.Ю., доктор экономических наук, кандидат геолого-минералогических наук, профессор отделения нефтегазового дела Инженерной школы природных ресурсов Национального исследовательского Томского политехнического университета.

Хатьков В.Ю., начальник департамента 817 ПАО «Газпром»; соискатель Национального исследовательского Томского политехнического университета. 


\title{
UDC 339.13:546.711
}

\section{CRITICAL COMMODITY FLOWS OF MANGANESE RAW MATERIALS IN RUSSIA}

\author{
Grigory Yu. Boyarko1, \\ gub@tpu.ru
}

\author{
Vitaly Yu. Khatkov², \\ V.Khatkov@adm.gazprom.ru \\ 1 National Research Tomsk Polytechnic University, \\ 30, Lenin Avenue, Tomsk, 634050, Russia. \\ 2 Gazprom, \\ 2, Pobedy square, St. Petersburg, 196143, Russia.
}

\begin{abstract}
The relevance of the work is caused by the need to study the problem of import dependence of Russia on manganese raw materials. The aim of the research is to study the dynamics of commodity flows (production, import, export, consumption) of manganese products (ores and concentrates, ferromanganese, silicomanganese and manganese metal); development of recommendations to optimize the turnover of manganese products.

Methods: statistical, graphic, logical.

Results. Manganese products are one of the most mass import-dependent goods in Russia. More than 1,6 million tons, which is $72 \%$ of their consumption, were imported in 2018. Import dependence on manganese ores as of 2018 is $100 \%$ of consumption $(1,3$ million tons were imported), silica manganese - $46 \%$ (import is 192 thousand tons), manganese metal - $100 \%$ (import is 68 thousand tons) and ferromanganese - $10 \%$ (import is 21 thousand tons). Consumption of manganese concentrate increased from 285 thousand tons in 1996 to 1,3 million tons in 2018 (+7,2 \%/year). In near future, the ferrous metallurgy of Russia will not be able to do without the import of manganese concentrate. Serious regulation of imports of manganese concentrate from Kazakhstan, South Africa and Gabon is required, as well as Russian investments in foreign manganese mining and ferroalloy companies. National consumption of silica manganese increased from 170 thousand tons in 1998 to 455 thousand tons in 2017 (+5,3\%/ year), and production increased from 50 to 355 thousand tons/year (+6,5\%/year). Import volumes of silicomanganese remain at the same level - 170-190 thousand tons/year, although in 2003-2008 import volumes were 310-435 thousand tons/year. The reduced imports from Ukraine were replaced by supplies from Georgia, Kazakhstan and Norway. National consumption of ferromanganese increased slightly - from 193 thousand tons in 1996 to 262 thousand tons in 2017 $(+0,6 \% / y e a r)$, and production volumes increased sharply from 50 to 260 thousand tons/year ( $+6,5 \% /$ year). The volume of imports of ferromanganese at the same time seriously decreased from 130 to 21 thousand tons/year (-3,9\%/year). Ferromanganese came out of full import dependence in import-independent category. The demand for a new commodity product - metallic manganese occurred. Its consumption increased from 0,3 thousand tons in 1996 to 68 thousand tons in 2018 (+12,2\%/year). In the context of total imports of manganese ferro-alloys the phenomenon of counter import-export trade (export to 63 thousand tons/year of ferromanganese and to 133 thousand t/year of silicomanganese), until the formation of the direction of net exports of ferromanganese (to 41 thousand tons/year of ferromanganese) appeared.
\end{abstract}

\section{Key words:}

Ferroalloy industry of Russia, manganese ores and concentrates, ferromanganese, silicomanganese, metal manganese, import dependence, counter commodity flows

\section{REFERENCES}

1. Trubetskoy K.N., Chanturiya V.A., Vorobyov A.E., Tigunov L.P. Marganets. Mineralno-syrevaya baza SNG. Dobycha i obogashchenie rud [Manganese. Mineral resource base of the CIS. Extraction and enrichment of ores]. Moscow, Mining Academy Publ., 1999. $271 \mathrm{p}$.

2. Tigunov L.P. State and prospects of development of raw materials base of ferrous metallurgy. Manganese ore. Mineralnye resursy Rossii. Ekonomika i upravlenie, 1994, no. 4, pp. 14-19. In Rus.

3. Schulz K.J., DeYoung J.H., Seal R.R., Bradley D.C. Critical minera resources of the United States - economic and environmental geology and prospects for future supply. Reston, U.S. Department of the Interior; U.S. Geological Survey. 2017. 862 p. Available at: https://pubs.usgs.gov/pp/1802/pp1802_entirebook.pdf (accessed: 6 October 2019).

4. Study on the review of the list of critical raw materials. Critical raw materials factsheets. Written by Deloitte Sustainability; British Geological Survey; Bureau de Recherches Géologiques et Minières; Netherlands Organisation for Applied Scientific Research. 2017. 515 p. Available at: https://publications.europa.eu/ en/publication-detail/-/publication/7345e3e8-98fc-11e7-b92d01aa75ed71a1 (accessed: 6 October 2019).

5. Public annual market research report [Manganese]. International Manganese Institute (IMI). 2016. 92 p. Available at: https://www.manganese.org/files/publications/PUBLIC\%20RESE
ARCH\%20REPORTS/2013_IMnI_Public_Report.pdf (accessed: 6 October 2019)

6. Gosudarstvenny doklad «O sostoyanii $i$ ispolzovanii mineralnosyrevykh resursov Rossiyskoy Federatsii v 2016-2017 godakh» [State report «State and use of mineral resources of the Russian Federation in 2016-2017]. Available at: http://www.mnr.gov.ru/ docs/o_sostoyanii i ispolzovanii mineralno_syrevykh resursov_r ossiyskoy_federatsii/gosudarstvennyy_doklad_o_sostoyanii_i_ ispolzovanii_mineralno_syrevykh_resursov_rossiyskoy_federatsii/ (accessed: 6 October 2019).

7. Federalnaya sluzhba gosudarstvennoy statistiki Rossii [Federal state statistics service of Russia]. Available at: https://gks.ru/emiss (accessed: 6 October 2019).

8. Federalnaya tamozhennaya sluzhba Rossii [Federal customs service of Russia]. Available at: http://stat.customs.ru/analytics/ (accessed: 6 October 2019)

9. TrendEconomy. Available at: http://data.trendeconomy.ru/ dataviewer/trade/statistics/ (accessed: 6 October 2019).

10. Informatsionno-analiticheskiy tsentr "Mineral» [Information and analytical center «Mineral»]. Available at: http://www.mineral.ru/ Center/index.html (accessed: 06 October 2019).

11. Tangstad M. Manganese ferroalloys technology (Book Chapter). Handbook of ferroalloys. Oxford (UK); Waltham (USA), Butterworth-Heinemann, 2013. pp. 221-266. DOI: 10.1016/B978-0-08097753-9.00007-1. 
12. Koloskova I.S. Structure of production and market of manganese raw materials in Russia. Mineralnye resursy Rossii. Ekonomika $i$ upravlenie, 2014, no. 1, pp. 74-77. In Rus.

13. Polulyakh L.A., Dashevskii V.Y., Yusfin Y.S. Manganeseferroalloy production from Russian manganese ore. Steel in Translation, 2014, vol. 44, no. 9, pp. 617-624. DOI: $10.3103 /$ S0967091214090125.

14. Leontev L.I., Zhuchkov V.I., Zhdanov A.V., Dashevskii V.Y. Ferroalloy production in Russia. Steel in Translation, 2015, vol. 45, no. 10 , pp. 773-777. DOI: 10.3103/S0967091215100101.

15. Lapteva A.M., Mitrofanov N.P., Tigunov L.P. Alloying metal supply: state-of-the art, problems and prospects. Gorny zhurnal, 2017, no. 7, pp. 10-16. DOI: 10.17580/gzh.2017.07.02 DOI: $10.17580 /$ gzh.2017.07.02 In Rus.

16. Boyarko G.Yu., Hatkov V.Yu. Commercial streams of ferroalloys in Russia. Chernye metally, 2018, no. 3, pp. 60-69. In Rus.

17. Dashevskii V.Y., Zhuchkov V.I., Leontev L.I. Utilization of manganese in Russian metallurgy. Steel in Translation, 2019, vol. 49 no. 1, pp. 50-57. DOI: 10.3103/S0967091219010042.

18. Khatkov V.Yu., Boyarko G.Yu. World and Russian counter import-export flows of mineral products. Bulletin of the Tomsk Polytechnic University. Geo assets Engineering, 2018, vol. 329, no. 3, pp. 145-167. In Rus.

19. Strategiya razvitiya chernoy metallurgii Rossii na 2014-2020 gody $i$ na perspektivu do 2030 goda [Strategy of development of ferrous metallurgy of Russia for 2014-2020 and for perspective till 2030]. By order of the Ministry of industry and trade Russia. 05.05.2014, no 839. Available at: https://www.garant.ru/products/ ipo/prime/doc/70595824/ (accessed: 6 October 2019).

20. Hodina M.A. Russian market of manganese products and potential possibilities of its import substitution. Razvedka i ohrana nedr, 2017, no. 2, pp. 42-48. In Rus.

21. Margantsevoe rudoobrazovanie na territorii SSSR [Manganese ore formation in the USSR]. Ed by D.G. Sapozhnikov. Moscow, Nauka Publ., 1984. 280 p.

22. Valshchikov A.V., Litvinenko A.P., Deler M. The project of development of the Usinsk Deposit of manganese. The technology of enrichment of ore. Mineralnye resursy Rossii. Ekonomika i upravlenie, 2011, no. 3, pp. 80-83. In Rus.

23. Dashevskii V.Y., Yusfin Y.S., Podgorodetskii G.S., Baeva N.V. Production of manganese ferroalloys from Usinsk manganese ore. Steel in Translation, 2013, vol. 43, no. 9, pp. 544-551. DOI: $10.3103 / \mathrm{S} 0967091213090052$

24. Primak V.S., Nebogov V.K., Spiridonova E.L. Prospects for the development of the Porozhinsky manganese Deposit in the Krasnoyarsk region. Gorny zhurnal, 2006, no. 8, pp. 23-27. In Rus.

25. Salikhov D.N., Kovalev S.G., Brusnitsyn A.I. Poleznye iskopaemye respubliki Bashkortostan (margantsevye rudy) [Minerals of the Republic of Bashkortostan (manganese ores)]. Ufa, Geology Institute AN of Bashkortostan Republic, 2002. 243 p.

26. Kontar E.S. Margantsevye mestorozhdeniya Urala [Manganese deposits of the Urals]. Ekaterinburg, KPR po Sverdlovskoy oblasti Publ., 1999. $118 \mathrm{p}$.

27. Kostyuk B.F., Ostrovskiy L.A., Penchuk V.N., Ilyushinov A.L. Margantsevonosnost polyarnogo Urala [Manganese content of the Polar Urals]. Sostoyanie margantsevo-rudnoy bazy Rossii $i$ voprosy obespecheniya promyshlennosti margantsem [State of manganese-ore base of Russia and issues of supporting industry with manganese]. Ekaterinburg, The Ekaterinburg Association of small business Publ., 2000. pp. 93-98.

28. Tsykin R.A. Hypergenic manganese ores of Central Siberia. Journal of Siberian Federal University. Series: Engineering and technology, 2008, vol. 1, no. 1, pp. 3-16. In Rus.

29. Vahrushev V.A., Pavlenko Yu.V. Chitinskaya oblast - novaya potencialnaya margantsevorudnaya provintsiya Rossii [Chita region - a new potential manganese province of Russia]. Sostoyanie margantsevo-rudnoy bazy Rossii $i$ voprosy obespecheniya promyshlennosti margantsem [State of manganese-ore base of Russia and issues of supporting industry with manganese]. Ekaterinburg, The Ekaterinburg Association of small business Publ., 2000. pp. 116-123.

30. Cherepanov A.A. Margantsevye rudy Dalnego Vostoka [Manganese ores of the Far East]. Sostoyanie margantsevo-rudnoy bazy Rossii $i$ voprosy obespecheniya promyshlennosti margantsem [State of manganese-ore base of Russia and issues of supporting industry with manganese]. Ekaterinburg, The Ekaterinburg Association of small business Publ., 2000. pp. 134-136.

31. Byhovskiy L.Z., Tigunov L.P., Mirchink I.M., Terentev V.B. Ferromanganese formations of the world ocean and sea shelf mineral raw materials of multipurpose purpose. Mineralnye resursy Rossii. Ekonomika i upravlenie, 2009, no. 2, pp. 17-24. In Rus.

32. Zubkov M.V., Plucinski P.K., Dartiguelongue A.C.Y., Lusty P.A.J. Metal extraction from deep-ocean mineral deposits. Elements, 2018, vol. 14, no. 5, pp. 319-324. DOI: 10.2138/gselements. 14.5.319

33. Lusty P.A.J., Murton B.J. Deep-ocean mineral deposits: Metal resources and windows into earth processes. Elements, 2018, vol. 14, no. 5, pp. 301-306. DOI: 10.2138/gselements.14.5.301.

34. UN Convention on the law of the sea. Done at Montego Bay on 10 December 1982 (Rev. from 23.07.1994). 193 p. Available at: https://www.un.org/depts/los/convention_agreements/texts/unclos/ unclos_e.pdf (accessed: 6 October 2019).

35. Rogozhin A.A., Temnov A.V., Tigunov L.P., Petrova N.V., Konoplev A.D. Modern technologies in effective development and development of mineral resources base of solid minerals of Russia. Razvedka i ohrana nedr, 2006, no. 7, pp. 33-41. In Rus.

36. Tigunov L.P., Ozhogina E.G., Litvintsev E.G., Bronickaya E.S., Anufrieva S.I., Kalish E.A. Modern technologies of enrichment and hydrometallurgical processing of manganese ores. Gorny zhurnal, 2007, no. 2, pp. 78-84. In Rus.

37. Chernobrovin V.P., Mizin V.G., Sirina T.P. Production of highquality manganese concentrates from carbonate ores. Stal, 2005, no. 1 , pp. 53-55.

38. Chernobrovin V.P., Mizin V.G., Sirina T.P., Dashevskiy V.Ya. Kompleksnaya pererabotka karbonatnogo margantsevogo syrya: khimiya i tekhnologiya [Complex processing of carbonate manganese raw materials: chemistry and technology]. Chelyabinsk, Centr YuUrGU Publ., 2009. 293 p.

39. Sokolova V.N., Anufrieva S.I., Temnov A.V., Borzykh O.S., Yakushina O.A. Prospects of application of heap leaching technology for processing of hard-to-enrich manganese ores. Razvedka $i$ okhrana nedr, 2011, no. 8, pp. 44-49. In Rus.

40. Das A.P., Ghosh S. Bioleaching of manganese from mining waste materials. Materials Today: Proceedings, 2018, vol. 5, no. 1, pp. 2381-2390. DOI: 10.1016/j.matpr.2017.11.459.

41. Zhukov D.Y., Averina Y.M. Development of a pyrometallurgical technology for processing synthetic pyrolusite and chemisorption manganese oxide concentrate into metallic manganese and lowcarbon ferroalloys. CIS Iron and Steel Review, 2019, vol. 17, pp. 25-29. DOI: 10.17580/cisisr.2019.01.04.

42. Streltsov V.I., Volkov Yu.I., Balashov A.G., Streltsova T.P. Complex development of subsoil by the method of borehole hydraulic mining. Gorny zhurnal, 2010, no. 7, pp. 33-36. In Rus.

43. Dashevskij V.Ya., Yusfin Yu.S., Aleksandrov A.A., Leontev L.I., Podgorodeckij G.S., Gubanov V.I. Improving manganese utilization in the production of manganese ferroalloys. Steel in Translation, 2013, no. 7, pp. 32-37. DOI: 10.3103/S0967091213070036.

44. Chirakadze A., Gurchumelia L., Khomeriki I., Toscano W.A., Bazghadze I., Geleishvili I., Gvakharia V., Geleishvili T. Complex processing of manganese bearing waste and low-grade ores by autoclaving method. International journal of global warming, 2016, vol. 10, no. 1, pp. 291-306. DOI: 10.1504/IJGW.2016.077919.

45. Zhuchkov V.I., Zhdanov A.V., Leontev L.I., Dashevskii V.Y. Calculations of manganese ferroalloys production efficiency from different ores. Steel in Translation, 2016, vol. 46, no. 11, pp. 814-817. DOI: 10.3103/S0967091216110139.

46. Zhukov D.Y., Averina Y.M., Menshikov V.V. Design of a hydrometallurgical complex for processing of complex low-grade manganese ores. CIS Iron and Steel Review, 2018, vol. 16, pp. 4-10. DOI: 10.17580/cisisr.2018.02.01.

47. Cheraghi A., Yoozbashizadeh H., Ringdalen E., Safarian J. Kinetics and mechanism of low-grade manganese ore reduction by natural gas. Metallurgical and Materials Transactions B: Process Metallurgy and Materials Processing Science, 2019, vol. 50, no. 4. pp. 1566-1580. DOI: 10.1007/s11663-019-01574-4.

48. Han P., Zhang G., Chu S. Reducing dephosphorization of silicomanganese ferroalloys by CaO-based slag. Metallurgical Research and Technology, 2017, vol. 114, no. 6, Article number 605. DOI: $10.1051 /$ metal/2017020. 
49. Tleugabulov S.M., Tazhiev E.B. Energy-saving ferroalloy production. Steel in Translation, 2017, vol. 47, no. 10, pp. 682-687. DOI: 10.3103/S0967091217100102.

50. Sithole N.A., Rambuda N., Steenkamp J.D., Hayman D.A., Hockaday C. Silicomanganese production at mogale alloys. Journal of the Southern African Institute of Mining and Metallurgy, 2018, vol. 118, no. 11, pp. 1205-1216. DOI: $10.17159 / 2411-$ 9717/2018/v118n11a11.

51. Khmelevskaya N.G. Priorities of Russia's foreign trade policy in the orbit of BRICS economic cooperation. Ekonomicheskaya politika, 2015, vol. 10, no. 2, pp. 93-109. In Rus.

Received: 14 November 2019.

\section{Information about the authors}

Grigory Yu. Boyarko, Dr. Sc., Cand. Sc., professorNational Research Tomsk Polytechnic University.

Vitaly Yu. Khatkov, head of the department 817, Gazprom. 